\title{
Selection of the initiator tRNA by Escherichia coli initiation factors
}

\author{
Dieter Hartz, David S. McPheeters, ${ }^{1}$ and Larry Gold ${ }^{2}$ \\ Department of Molecular, Cellular, and Developmental Biology, University of Colorado, Boulder, Colorado 80309 USA
}

\begin{abstract}
We have developed a new technique, called 'toeprinting,' which has allowed a study of the tRNA-binding properties of Escherichia coli translation initiation complexes. In response to natural mRNAs, the initiator tRNA and a variety of elongator tRNAs bind to the same tRNA-binding site on the $30 \mathrm{~S}$ ribosomal subunit as long as a cognate codon is present near the Shine and Dalgarno sequence. The selection of the initiator tRNA in $30 S$ initiation complexes is accomplished by initiation factors IF2 and IF3. 70S ribosomes accept both initiator tRNA and elongator tRNAs on natural mRNAs, much like 30S ribosomal subunits; IF3 and IF2 do not, however, select the initiator tRNA on 70S initiation complexes unless the initiation factor IF1 is present.
\end{abstract}

[Key Words: Initiation factors; ribosomes; ribosome-binding sites; tRNA]

Received June 29, 1989; revised version accepted September 19, 1989.

The process of translation initiation in Escherichia coli has been the subject of extensive experimentation over the last 25 years. Some recent reviews have focused on the mRNA requirements for rapid initiation at a particular ribosome-binding site (Gold et al. 1981; Stormo 1986; Gold and Stormo 1987; Gold 1988). The role of various sequence elements within a mRNA is now clear, particularly the Shine and Dalgarno domain and the initiation codon. Other reviews have focused on the non-mRNA components used for translation initiation on most mRNAs; these include the 30S ribosomal subunit, charged and formylated initiator tRNA, three initiation factors, and GTP (Maitra et al. 1982; Kozak 1983; Gualerzi et al. 1986; Hershey 1987). A consensus pathway for translation initiation in $E$. coli includes the formation of a $30 \mathrm{~S}$ initiation complex intermediate, in which the initiator tRNA is bound to the $30 \mathrm{~S}$ subunit (which is bound, itself, on the mRNA at the ribosomebinding site). The initiator tRNA is base-paired with the initiation codon (Guthrie and Nomura 1968; Gualerzi and Pon 1981; Hershey 1987). The initiation factors IF1, IF2, and IF3 (as well as GTP) catalyze $30 \mathrm{~S}$ initiation complex formation (Wintermeyer and Gualerzi 1983). During or after the joining of the 50S subunit to the $30 \mathrm{~S}$ initiation complex, the initiation factors are released, GTP is cleaved, and a 70S initiation complex is formed.

The precise mechanism by which each component acts is not well understood. Evidence has been presented that the 30 S ribosomal subunit is competent for mRNA binding and initiation site recognition on an mRNA without the participation of any other component (Van Duin et al. 1980). Furthermore, initiator tRNA can be

${ }^{1}$ Present address: Division of Biology, 147-75 California Institute of Technology, Pasadena, California 91125 USA.

${ }^{2}$ Corresponding author. bound into such $30 \mathrm{~S}$ binary complexes in the absence of initiation factors (Nomura and Lowry 1967), and even elongator tRNA can be bound (Hartz et al. 1988). Polynucleotide-directed protein synthesis can start with the initiator tRNA or elongator tRNAs and can proceed in the absence of initiation factors (Wahba et al. 1969; Hershey 1987). In contrast, natural mRNA-directed protein synthesis always starts with the initiator tRNA and requires initiation factors. Thus, the initiation factors might be involved in the selection of the initiator tRNA (Gold 1988). Some portion of the literature on initiation factors points toward this simple view: Initiation factors IF2 and IF3 could provide the selective recognition of the initiator tRNA (Jay and Kaempfer 1974; Pon and Gualerzi 1974; Risuleo et al. 1976; Van der Hofstad et al. 1977). However, the literature includes suggestions of other roles for the initiation factors. Initiation factors IF3 and, to a lesser extent, IF1, have been implicated in the 70 dissociation (Subramanian and Davis 1970; Kaempfer 1972; Godefroy-Colburn et al. 1975). IF3 has also been implicated in the binding of the $30 \mathrm{~S}$ subunit to the mRNA (Wahba et al. 1969; Suttle and Ravel 1974; Hershey 1987). Some suggestions that the 30S particle has an intrinsic high affinity site for the initiator tRNA would make the selection of initiator tRNA by the initiation factors superfluous (Bretscher and Marcker 1966; Nomura and Lowry 1967).

No experiments have been published in which initiation factors can be observed directly selecting the initiator tRNA over elongator tRNAs. The experiments reported here use a new method for inspecting ribosomes bound to mRNAs at translation initiation regions. The method, called extension inhibition, or toeprinting (Hartz et al. 1988), involves nothing more than cDNA synthesis by reverse transcriptase on a template mRNA on which a ribosome, together with a tRNA, is bound. 
The position of reverse transcriptase terminations depends on the exact position of the mRNA with respect to the bound ribosome which, in turn, depends on the tRNA species bound in the ribosome. Our data show that ribosomes recognize translational initiation regions but do not discriminate strongly between tRNAs. However, the initiator tRNA can be selected over other tRNAs by the initiation factors.

\section{Results}

\section{Principle of the toeprinting method}

A ternary complex consisting of the $30 \mathrm{~S}$ ribosomal subunit, tRNA, and mRNA stops reverse transcriptase that started cDNA synthesis downstream of the ribosomebinding site (Fig. 1; Hartz et al. 1988). The premature reverse transcriptase stop, called a toeprint, is located easily on a sequencing gel. Toeprinting does not call for an extensive purification of the RNA because a $5^{\prime 32}$-labeled primer can provide the assay specificity. Furthermore, we can easily monitor the bound tRNA species (Hartz et al. 1988). The strength of the toeprint versus the extent to which reverse transcriptase reads through to the $5^{\prime}$ end of the mRNA is a quantitative measure of the formation and stability of the initiation complexes (Winter et al. 1987; McPheeters et al. 1988; Bläsi et al. 1989; D. Hartz et al., in prep.).

\section{Toeprint signals from many different ribosome-binding sites}

In our first report of toeprinting (Hartz et al. 1988), we noticed that gene 32 mRNA /whose initiation codon is followed by a phenylalanine codon/ yielded a toeprint with either initiator tRNA or tRNA ${ }^{\text {Phe }}$. The toeprints appeared 15 nucleotides $3^{\prime}$ to the first nucleotide of their respective codons. If the $P$ site on the $30 \mathrm{~S}$ particle can bind different tRNAs and if the initiation scheme outlined above is correct, the position of a toeprint would logically depend on cognate codon/anticodon pairing between the bound tRNA and the mRNA. We asked whether the +15 distance between cognate codon and toeprint position is general and over what range codons are inspectable near the Shine and Dalgarno sequence during initiation. Toeprinting with $30 \mathrm{~S}$ subunits and fMet-tRNA ${ }_{f}^{\text {Met }}$ works with a wide variety of mRNAs

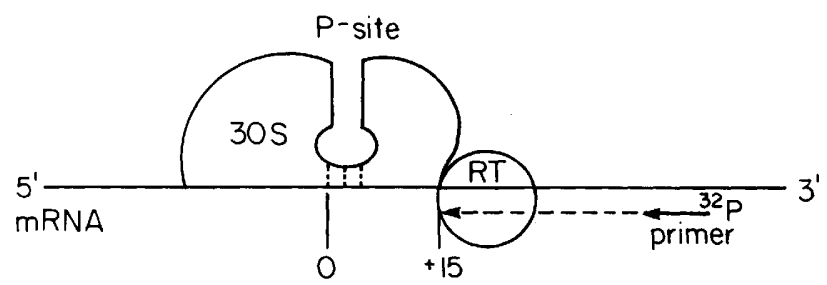

Figure 1. Model for the toeprinting method. Reverse transcriptase terminates cDNA synthesis when it encounters a $30 \mathrm{~S}$ particle and tRNA bound on the mRNA at the ribosomebinding site. from T4-infected cells and also with transcripts prepared in vitro with T7 RNA polymerase (Fig. 2, lanes 3; Table 1). In most cases, reverse transcriptase stops +15 downstream from the first nucleotide of the actual initiation codon. In a several cases, toeprints occur at both +15 and +16 , and in one case, an additional weak toeprint signal occurs at +14 (orf $D$ ). The T4 gene 1 mRNA was unique in that only a single stop at +17 was observed. The toeprint position at +15 with gene 32 mRNA is reproducible with reverse transcriptases from two different sources-avian myeloblastosis and Moloney murine leukemia virus (AMV and MMLV) - and even with the Klenow fragment of $E$. coli DNA polymerase I when single-stranded DNA is used as a mRNA (data not shown). The data support the idea, as discussed in Hartz et al. (1988), that these enzymes synthesize cDNA right up to the edge of the ribosome in the ternary complex and that the distance between the ribosome's downstream edge and the first base of the initiation codon approximates 13-14 nucleotides.

When crude mRNA preparations are used as tem-

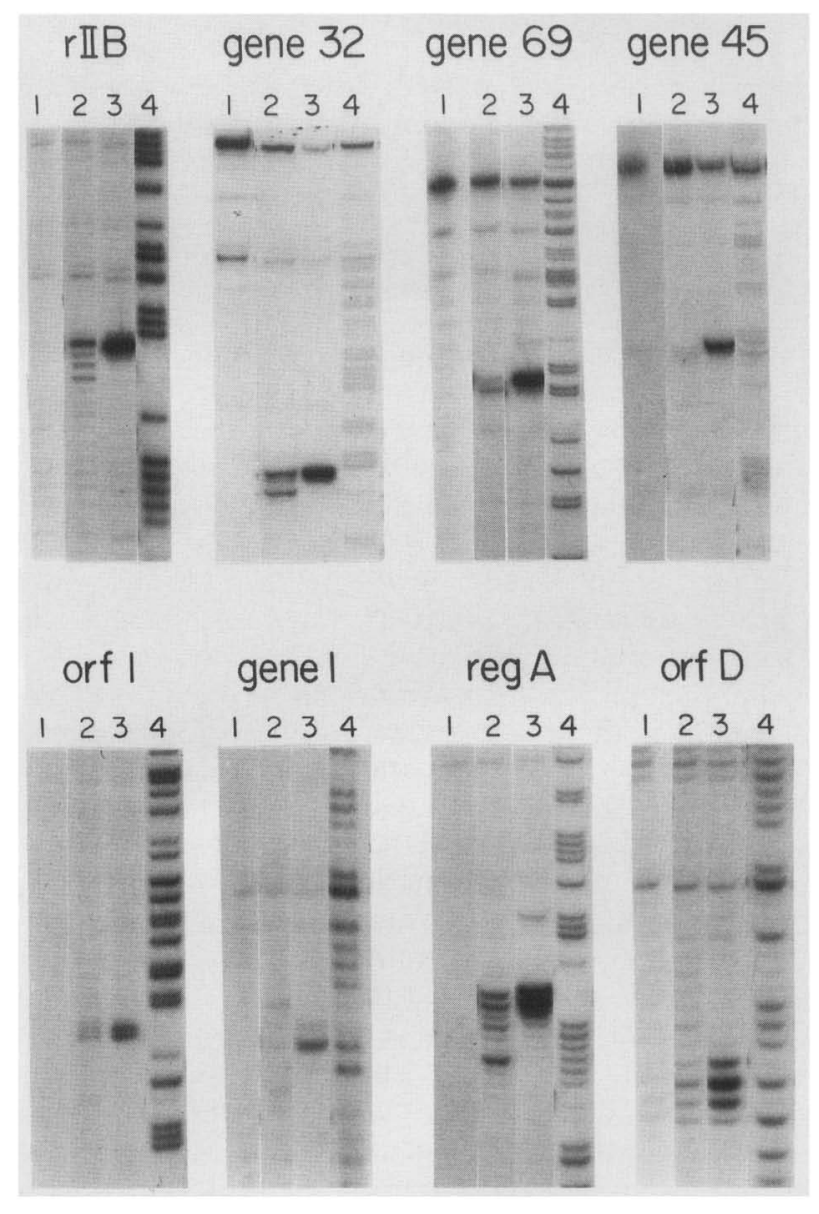

Figure 2. Detection of ternary complexes on various T4 mRNAs (crude mRNA) by toeprinting analysis. Reactions contained neither 30S nor tRNA (lanes 1), $1 \mu \mathrm{M} 30 \mathrm{~S}$ subunits (lanes

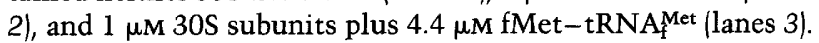
Preincubation was for $5 \mathrm{~min}$ at $37^{\circ} \mathrm{C}$ before AMV reverse transcriptase was added. (Lanes 4) Sequencing lanes (A lanes). 
Table 1. Summary of toeprints obtained from Figures 2 and 3.

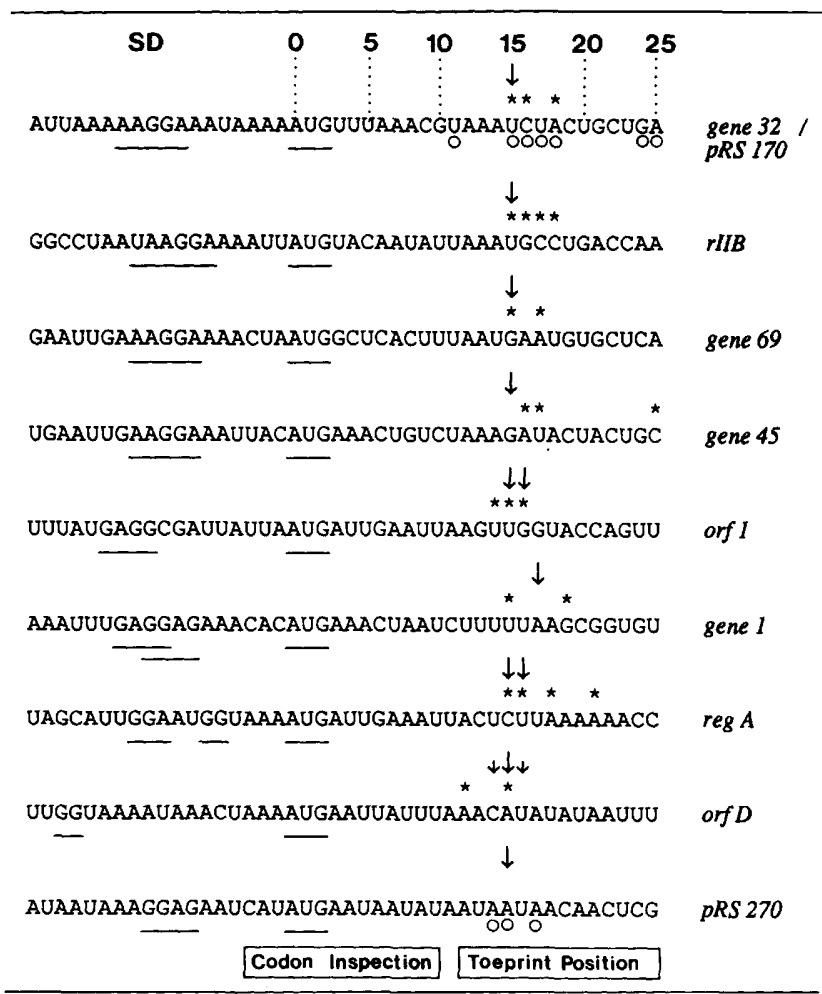

Toeprint positions with $\mathrm{fMET}$-tRNAMet are indicated by vertical arrows. Toeprint positions resulting from endogenous tRNAs in the crude mRNA preparation are indicated by asterisks $\left({ }^{*}\right)$. Toeprint positions from pure tRNAs used with in vitro transcripts are indicated by open circles $(O)$. SD sequences and initiation codons are underlined.

plates, weak toeprints appear in the neighborhood of the +15 stop even in the absence of added fMet-tRNA $\mathrm{f}_{\mathrm{f}}^{\mathrm{Met}}$ (Fig. 2, lanes 2; Table 1). We hypothesize that these stops are caused by ternary complexes formed with endogenous tRNAs in crude mRNA preparations. These stops are absent when in vitro transcripts are used without added tRNA (Fig. 3, lane 2). The stops do not represent $30 S$ mRNA binary complexes, which are not stable enough to withstand reverse transcription at $37^{\circ} \mathrm{C}$ under these conditions (Fig. 3 lane 2; D. Hartz, unpubl.).

To prove that the weak toeprints seen in Figure 2 (lanes 2; crude mRNA preparations plus 30S, no initiator tRNA addition) are caused by endogenous tRNAs and to find out which elongator tRNAs are capable of ternary complex formation, we used the pRS170 in vitro transcript, which contains the gene 32 ribosome-binding site. When total E. coli tRNA $(0.5 \mu \mathrm{g})$ plus $30 \mathrm{~S}$ subunits $(0.2 \mu \mathrm{M})$ were added to toeprinting reactions, exactly the same stops were seen as for gene 32 in vivo RNA in Figure 2, lane 2 (data not shown). We also tested single, uncharged tRNA species. Besides tRNA $\mathrm{f}_{\mathrm{f}}^{\text {Met }}$, a variety of elongator tRNAs give toeprints if cognate codons are in the neighborhood of the real initiation codon. On the pRS170 transcript, tRNA met, tRNA ${ }^{\text {Cys }}$, tRNA ${ }^{\text {val }}$ - 1 , tRNA $^{\text {Val }}-2$, tRNA ${ }^{\text {Phe }}$, tRNA ${ }^{\text {Lys }}$, and tRNA ${ }^{\text {Arg- }} 1$ all resulted in toeprints of variable strength, +15 from the first nucleotide of their cognate codons (Fig. 3; Table 1; tRNA ${ }^{\text {Asn }}$, which recognizes the codons AAU and AAC, and $\mathrm{tRNA}^{\mathrm{Thr}}-4$, which recognizes the codon ACG, were not tested). This indicates that elongator tRNAs bind to the same tRNA-binding site on the $30 \mathrm{~S}$ subunit as the initiator TRNA and that they reposition the mRNA with respect to the $30 \mathrm{~S}$ subunit as codon/anticodon basepairing occurs. The tRNA-binding site almost certainly is a portion of the ribosomal P site (Gnirke and Nierhaus 1986). Some toeprints appear +15 from 'incorrect' codons (Fig. 3; tRNA ${ }^{\text {Val }_{-}}$, tRNA Val $_{-2}$, tRNA ${ }^{\text {Leu }}-5$, tRNA ${ }^{\text {Lys }}$, and tRNA Arg-1), which we attribute either to contamination of the 'pure' tRNAs with other tRNAs or to possible double toeprints from one tRNA, as observed previously with $\mathrm{fMet}-\mathrm{tRNA} \mathrm{f}_{\mathrm{f}}^{\text {Met }}$ (Table 1). Miscoding by $P$ site wobble is also possible. Many more tRNA species were tested whose cognate codons were farther away from the initiation codon. Almost all gave incorrect toeprints at similar positions as those described above (data not shown). In addition, several tRNAs gave very weak toeprints at a distant cognate codon, not unlike that seen with tRNA ${ }^{\text {Arg- }} 1$. Thus, the $30 \mathrm{~S}$ particle forms $30 \mathrm{~S}$ complexes mostly at codons that are within a window of -3-17 nucleotides from the Shine and Dalgarno sequence (Table 1). An accumulation of toeprints, in-

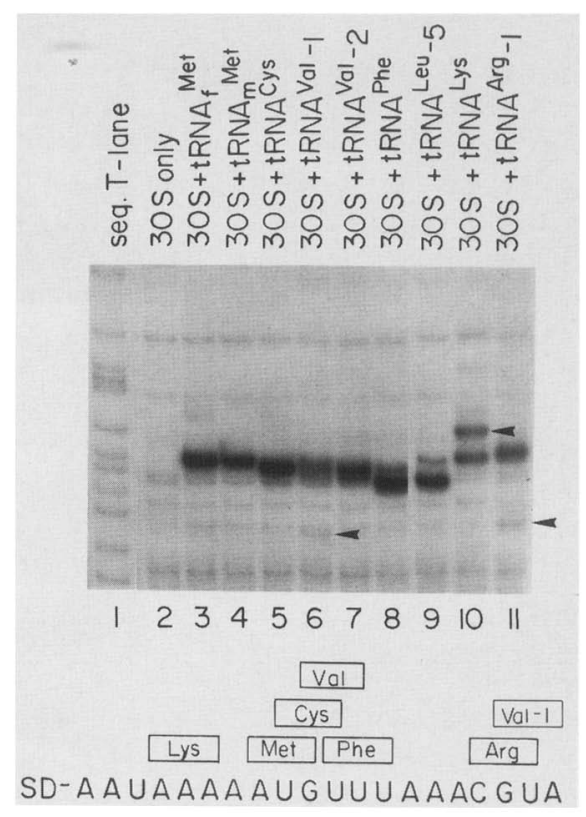

Figure 3. Detection of ternary complexes on the pRS170 in vitro transcript (containing the gene 32 ribosome-binding site) with several uncharged tRNA species. $30 \mathrm{~S}$ subunits were at $0.25 \mu \mathrm{M}$, and tRNAs at $1.25 \mu \mathrm{M}$. Preincubations were for 10 min at $37^{\circ} \mathrm{C}$, followed by primer extension with MMLV reverse transcriptase. The sequence 3 ' to the Shine and Dalgarno (SD) sequence is shown, together with the codons recognized by the tRNAs tested. The toeprint from tRNA ${ }^{\text {val }_{-} 1}$ that results from the reading of the downstream GUA codon and toeprints from tRNA ${ }^{\text {Lys }}$ and tRNA ${ }^{\text {Arg- }} 1$ that result from the reading of the cognate codons are marked with arrowheads. Note the accumulation of toeprinting signals at a certain distance from the SD sequence. (Lane 1) Sequencing lane (T lane). 
cluding the strongest ones, is observed within a narrower range of $\sim 7-10$ nucleotides from the Shine and Dalgarno sequence (Fig. 3; Table 1). The toeprints of

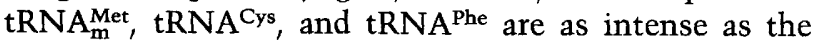
toeprint from $\mathrm{tRNA}_{\mathrm{f}}^{\mathrm{Met}}$, indicating that about equal amounts of complexes had formed. Weaker toeprints are formed by the other elongator tRNAs. This finding corresponds exactly to the previous result with crude gene 32 RNA (Fig. 2, gene 32, lane 2). Of the endogenous elongator tRNAs, tRNA ${ }^{\mathrm{Cys}}$ and $\mathrm{tRNA}^{\text {Phe }}$ compete well with the tRNAMet for the ribosomal $P$ site. Good competition with the tRNA $A_{f}^{\text {Met }}$ is also observed on the crude mRNAs of gene 69, gene 45, gene 1, and $\operatorname{reg} A$ (Fig. 2, lanes 2). Weak competition of the elongator tRNAs with the tRNA Met $^{\text {Met }}$ is observed on the crude mRNAs of $r I I B$, orf1, and orfD (Fig. 2, lanes 2) and on the pRS270 in vitro transcript with added tRNA (data not shown). Thus, elongator tRNAs compete well with $\mathrm{TRNA}_{\mathrm{f}}^{\text {Met }}$ for the 30S P site, in contrast to the notion that the $P$ site has the highest affinity for initiator tRNA and discriminates against any elongator tRNA (Bretscher and Marcker 1966; Nomura and Lowry 1967). A summary of the toeprint data on all mRNAs with endogenous or pure tRNAs is shown in Table 1 , which is discussed fully below.

\section{Comparison of $A 22_{f}^{M e t}, t R N A_{f}^{\text {Met }}$, and fMet-tRNA $A_{f}^{\text {Met }}$ in} $30 S$ ternary complexes

In the experiments presented so far, both tRNA Met $_{\text {(Fig. }}$ 3) and fMet-tRNA Met (Fig. 2) have been used. Both initiator tRNA species are able to form ternary complexes. Because either might be used in competition experiments with elongator tRNAs, we compared their binding characteristics on $30 S$ complexes. At a constant, saturating $30 \mathrm{~S}$ subunit level, increasing amounts of tRNA were added to toeprinting reactions containing the pRS170 transcript (Fig. 4). The relative toeprints were determined by densitometry from the autoradiographs (see Materials and methods). The relative toeprints do not reach $100 \%$ at apparently saturating concentrations of tRNA. This could be due to several causes; the complex formation has not gone to completion because the equilibrium is not reached yet (we know that this is correct, because longer preincubation increases the relative toeprint) and/or the equilibrium does not strongly favor the ternary complex. Alternatively, the reverse transcriptase might displace some of the complexes or wait for complex dissociation that is followed by rapid extension. The binding curves were adjusted to $100 \%$ binding range so that a best fit of our data with a bimolecular binding curve could be obtained (Fig. 5). The binding constants of tRNA $A_{f}^{\text {Met }}$ $\left\langle K_{\mathrm{a}}=7.4 \times 10^{7} / \mathrm{M}\right.$ and $\mathrm{fMet}-\mathrm{tRNA} \mathrm{f}_{\mathrm{f}}^{\text {Met }}\left(K_{\mathrm{a}}=1.0 \times 10^{8}\right)$ M) are not significantly different. Much weaker binding was observed for a synthetic anticodon stem and loop fragment of the initiator tRNA 'A22 Met' $\left(K_{\mathrm{a}}=1.8 \times 10^{6} / \mathrm{M}\right.$; Figs. 4-6).

Selection of the initiator $t R N A$ on $30 S$ complexes by IF3 Because many different tRNAs can bind to the $30 \mathrm{~S}$ sub-

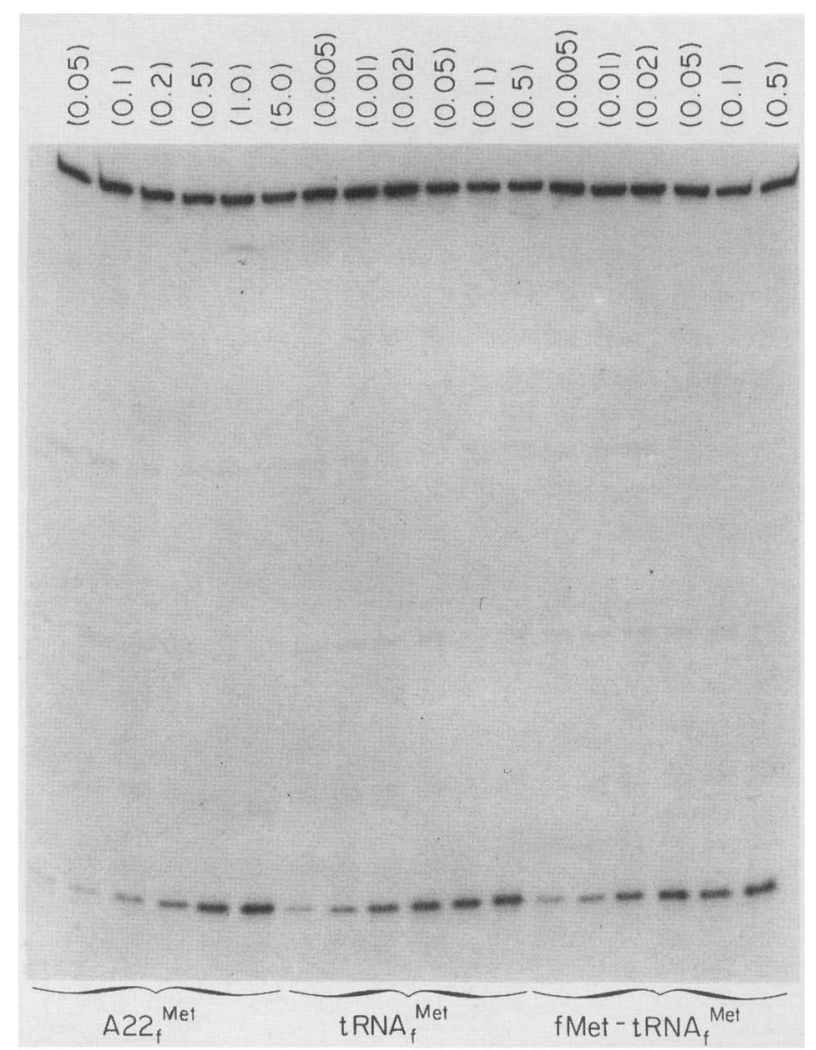

Figure 4. Dependence of ternary complex formation on tRNA concentration. At constant $30 \mathrm{~S}$ subunit concentration of 0.2 $\mu \mathrm{M}$, increasing amounts of the initiator tRNA fragment A22 Met (Fig. 6), tRNA ${ }^{\text {Met }}$ or fMet-tRNAMet were added at the concentrations $(\mu \mathrm{M})$ indicated above the corresponding lanes. Preincubations were for $10 \mathrm{~min}$ at $37^{\circ} \mathrm{C}$.

unit in response to a cognate codon within the ribosome-binding site (Figs. 2 and 3), there should be a mechanism in vivo that restricts the access of elongator tRNAs to the P site. IF3 has been shown to selectively destabilize polynucleotide-primed 305 complexes formed with elongator tRNAs (Pon and Gualerzi 1974; Risuleo et al. 1976). Therefore, we included purified IF3 in toeprinting reactions that contained both initiator tRNA and elongator tRNAs. An equimolar mixture of tRNA $\mathrm{t}_{\mathrm{f}}^{\mathrm{Met}}$, tRNA ${ }^{\mathrm{Cys}}$, and tRNA ${ }^{\text {Phe }}$ produces toeprints of equal strength at +15 from their cognate codons on the pRS170 transcript (Fig. 7). As increasing amounts of IF3 are added, the tRNA $A_{f}^{\text {Met }}$ toeprint prevails over the other two. At higher IF3 levels (IF3/30S ratio $>1$ ), even the

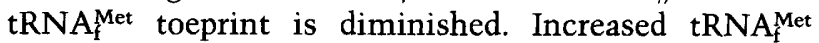
levels do not restore the diminished toeprint, so the kinetic effects of IF3 cannot be a result of an interaction of IF3 with free tRNA (data not shown). tRNA Met $_{\text {Ms }}$ as well selected as $\mathrm{fMet}-\mathrm{tRNA} \mathrm{f}_{\mathrm{M}}^{\mathrm{et}}$ in the competition reaction (Fig. 7, lanes 8 and 9). Finally, IF3 selects tRNA Met $_{\text {Mn }}$ mixed tRNA incubations even after the complexes have formed (Fig. 7, lane 10). IF3 must play an important role in the initiator tRNA selection, and the recognition signals for IF3 action are located in the RNA part of the tRNA. The recognition signal cannot be just the codon- 
$\%$ max. binding

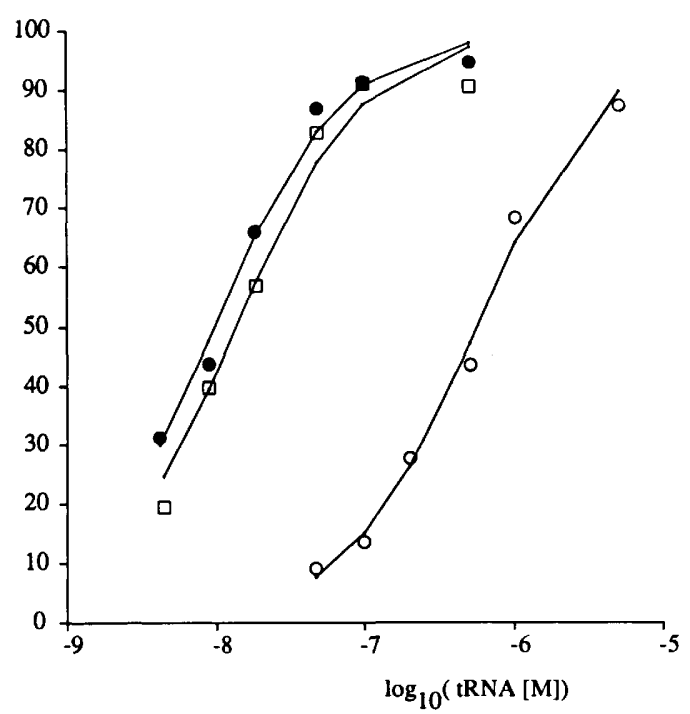

Figure 5. Semilogarithmic plot of scanning data from Fig. 4. The curves shown are the best fits to a theoretical binding curve. Saturation was assumed to be $100 \%$ for a relative toeprint of $40 \%$ for fMet-tRNA Met $(\bullet), 42 \%$ for tRNAMet $(\square)$, and $53 \%$ for $\mathrm{A} 22$ Met $($ 이, respectively.

anticodon interaction because tRNA $\mathrm{m}_{\mathrm{m}}^{\text {Met }}$ behaves like an elongator tRNA with respect to IF3.

Then we tried $\mathrm{A} 22_{\mathrm{f}}^{\text {Met }}$ in competition with tRNA ${ }^{\text {Cys }}$ and tRNA $^{\text {Phe }}$ (Fig. 8). As expected from its weaker binding constant, $\mathrm{A} 22_{\mathrm{f}}^{\text {Met }}$ does not compete efficiently with the two elongator tRNAs. Nevertheless, the fragment is selected at high IF3 concentration (IF3/30S ratio $=4$; Fig. 8). To further elucidate the mechanism of IF3, we studied its influence on ternary complex formation in toeprinting reactions with single tRNA ${ }^{\text {Met }}$ species; elongator tRNA $\mathrm{m}_{\mathrm{m}}^{\text {Met }}$ and initiator tRNA $\mathrm{Ret}_{\mathrm{f}}^{\text {Met }}$ behave differently with respect to IF3 (Fig. 9A,B). At a $1: 1$ ratio of IF3/30S, the tRNA Met toeprint is increased, whereas the tRNA $\mathrm{met}_{\mathrm{m}}^{\text {Met }}$ toeprint is slightly decreased. At high IF3 concentration (IF3/30S ratio $=4$ ) tRNA $_{\mathrm{f}}^{\text {Met }}$ binding is diminished, whereas tRNA Met binding is not detectable. The $\mathrm{A} 22_{\mathrm{f}}^{\mathrm{Met}}$ fragment behaves like tRNA $\mathrm{f}_{\mathrm{f}}^{\mathrm{Met}}$ and might thus contain the critical features of the initiator tRNA for the discrimination by IF3. The elongator tRNA ${ }^{\text {Phe }}$ behaves similarly to tRNA $\mathrm{m}_{\mathrm{m}}^{\text {Met }}$ (data not shown).

Selection of the intiator $t R N A$ on $30 S$ complexes by IF2

Initiation factor IF2 stimulates the binding of fMettRNA $A_{f}^{\text {Met }}$ into $30 S$ initiation complexes (Dubnoff et al. 1972; Vermeer et al. 1973; Jay and Kaempfer 1974), but IF2 also stimulates the binding of several elongator tRNAs into polynucleotide-primed $30 \mathrm{~S}$ particles (Canonaco et al. 1986). To determine whether IF2 could select the initator tRNA over elongator tRNAs on 30S complexes, we added IF2 with an equimolar mixture of $\mathrm{fMet}^{\mathrm{T}}$-tRNA ${ }_{\mathrm{f}}^{\text {Met }}$, tRNA ${ }^{\mathrm{Cys}}$, and tRNA ${ }^{\text {phe }}$, again using the pRS170 transcript. IF2 selects the fMet-tRNA ${ }_{i}^{\text {Met }}$ toe- print over the other two (Fig. 10). When added together with IF2, the initiation factor IF1 improves the selection marginally (Fig. 10, lane 6). IF2 does not select uncharged tRNA Iet $_{\mathrm{f}}$ under otherwise identical conditions (Fig. 10, lane 2). Thus, IF2 selects the initiator tRNA by virtue of at least its formylated methionine; direct tRNA inspection is also possible. Preliminary experiments suggest that the formyl group is essential for the selection (data not shown). Unlike IF3 (Fig. 7, lane 10), IF2 is unable to dissociate elongator tRNAs from preformed complexes to select the initiator tRNA (Fig. 10, lane 8 ; the increase of the fMet-tRNA ${ }_{f}^{\text {Met }}$ toeprint over the control lane is a result of extended complex formation after the preincubation period).

\section{Selection of the initiator $t R N A$ on $70 S$ complexes}

$70 \mathrm{~S}$ ribosomes have different tRNA-binding properties than 30S subunits (Nomura and Lowry 1967). We compared factor-free $70 \mathrm{~S}$ initiation complexes with $30 \mathrm{~S}$ complexes in toeprinting reactions. We used the pRS170 transcript again as a 'natural' mRNA template. Three elongator tRNAs ( $t R N A_{m}^{\text {Met }}$, tRNA ${ }^{\text {Cys }}$, and tRNA ${ }^{\text {Phe }}$ ) yield toeprints with factor-free $70 \mathrm{~S}$ ribosomes, just like $30 \mathrm{~S}$ subunits (Fig. 11). The toeprints occur at the same position $(+15)$ from the cognate codons as in $30 \mathrm{~S}$ complexes, but they are weaker than the corresponding $30 \mathrm{~S}$ toeprints. Toeprints probably result from a collision between reverse transcriptase and the $30 \mathrm{~S}$ subunit,

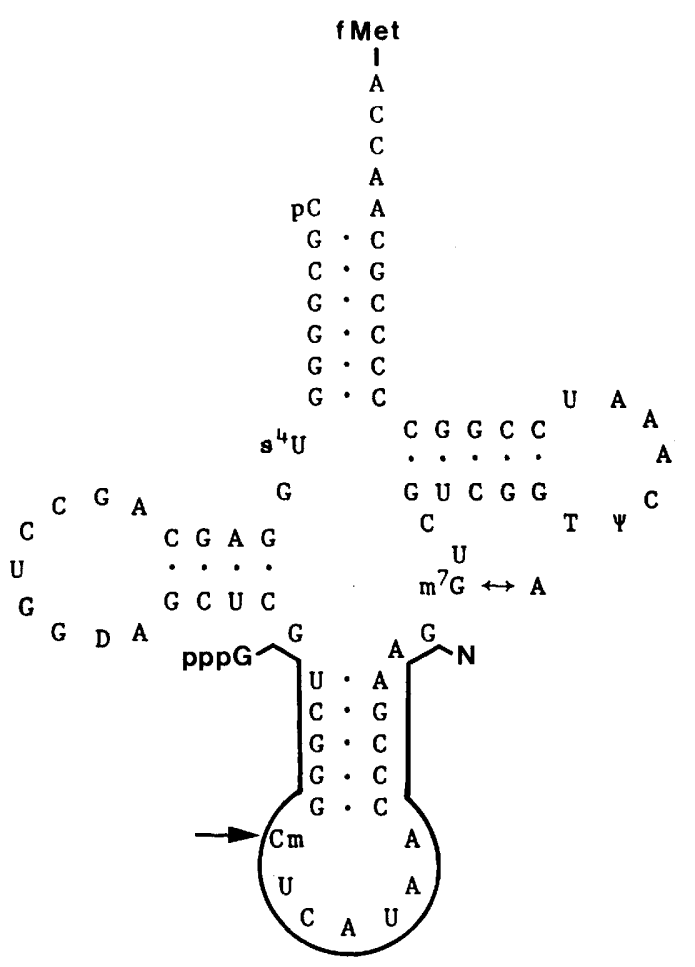

Figure 6. Sequence and structure of $\mathrm{A} 22_{\mathrm{fet}}^{\mathrm{Met}}$ is outlined as part of $\mathrm{fMet}-\mathrm{tRNA} \mathrm{f}_{\mathrm{M}}^{\mathrm{Met}}$. Note the extra pppG on its $5^{\prime}$ end and the extra random nucleotide $(N)$ on its $3^{\prime}$ end; the cytidine in the anticodon loop is unmodified. 


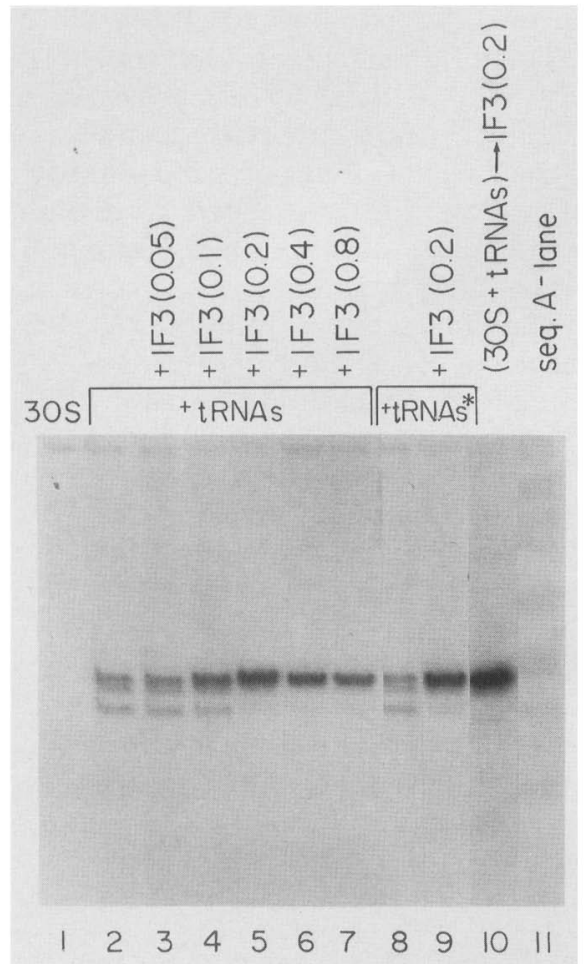

Figure 7. Selection of the initiator tRNA by IF3. In addition to $0.2 \mu \mathrm{M}$ 30S subunits (lane 1), a mixture of the three tRNA species tRNA ${ }^{\text {Met }}$, tRNA ${ }^{\text {Cys }}$, tRNA ${ }^{\text {Phe }}$ (tRNAs) at $0.5 \mu \mathrm{M}$ each (lanes 2-7 and 10) or a mixture of fMet-tRNA ${ }^{\text {Met, tRNACys, }}$ tRNA $^{\text {Phe }}$ (tRNAs ${ }^{*}$ ) at $0.5 \mu \mathrm{M}$ each (lanes 8 and 9 ) was added in the toeprinting reactions. Furthermore, IF3 was added in the concentrations $(\mu \mathrm{M})$ shown above the corresponding lanes. Preincubations were for $10 \mathrm{~min}$ at $37^{\circ} \mathrm{C}$. (Lane 10 ) The reaction containing $30 \mathrm{~S}$ and the tRNA mixture was preincubated for 10 min before IF3 was added and the preincubation continued for another $10 \mathrm{~min}$. Lane 11 contains the sequencing reaction (A lane).

whether or not the $50 \mathrm{~S}$ particle is present, that is, the $50 \mathrm{~S}$ particle is positioned away from the elongating reverse transcriptase. Furthermore, the fact that the toeprints are at the same position suggests that the tRNA site used is the same in every complex and is probably equivalent to the $P$ site. The $70 S$ initiation complexes are different from $30 \mathrm{~S}$ complexes; IF3 excludes the elongator tRNAs from $30 \mathrm{~S}$ but not from $70 \mathrm{~S}$ complexes (cf. Fig. 11, lanes 9 and 10), in accordance with previous results (Gottlieb and Davis 1975; Risuleo et al. 1976; Van der Hofstad et al. 1978). Preformed 30S complexes can be chased into $70 \mathrm{~S}$ complexes by adding $50 \mathrm{~S}$ subunits (Fig. 11, lanes 11 and 12). In mixed tRNA incubations, tRNA $^{\text {Cys }}$ and tRNA ${ }^{\text {Phe }}$ compete with the tRNA ${ }^{\text {Met }}$ for the same tRNA-binding site on the 70S ribosome, and the resulting toeprints are of about equal strength (Fig. 12 , lane 3). If, however, fMet-tRNA $A_{f}^{\text {Met }}$ is used in such a competition experiment, it forms $70 \mathrm{~S}$ ternary complexes to a lesser extent than the competing elongator tRNAs (Fig. 12, lane 4). Such behavior is not seen in 30S complexes (Fig. 12, lanes 1 and 2). These facts indicate that
$70 S$ complexes are formed directly and not via 305 complex intermediates, because $30 \mathrm{~S}$ intermediates would accept fMet-tRNA $\mathrm{f}_{\mathrm{fet}}$ and the elongator tRNAs equally well. The $70 \mathrm{~S}$ ribosome is able to find the ribosomebinding site on a message, yet it discriminates against fMet-tRNA $A_{f}^{\text {Met }}$. This discrimination appears only in competition experiments and not with the single tRNA (Fig. 12, lanes 5 and 6).

To investigate whether the initiation factors IF3 and IF2 select the initiator tRNA on 70S complexes, we included both factors in tRNA competition experiments with $70 \mathrm{~S}$ ribosomes on the pRS170 trancript. Neither IF3 nor IF2 selects fMet-tRNA ${ }_{\mathrm{f}}^{\text {Met }}$ over tRNA ${ }^{\text {Cys }}$ and tRNA $^{\text {Phe }}$ on 70 S complexes (Fig. 13, lanes 2 and 3). A combination of IF2 and IF3 leads to an increase of the fMet-tRNA ${ }_{\text {Met }}$ toeprint (Fig. 13, lane 4). A surprising result is obtained when initiation factor IFl is added. Even though this factor, itself, does not select fMet-tRNA fet $_{\mathrm{f}}$ (Fig. 13, lane 5), the toeprint from fMet-tRNA $\mathrm{f}_{\mathrm{f}}^{\text {Met }}$ is enhanced when IF1 is employed together with IF2 or IF3 (Fig. 13 lanes 6 and 7). Both combinations lead to a stronger selection of the initiator tRNA than the combination of IF2 + IF3. The effect is very striking when all three factors are employed; all three initiation factors yield a clear selection of fMet-tRNA Met (Fig. 13, lane 8). The selection is lost when uncharged tRNA (Fig. 13, lane 10). Because IF1 does not select the initiator tRNA on $30 \mathrm{~S}$ or $70 \mathrm{~S}$ complexes, it is likely that IF1 somehow enables IF3 and IF2 to select fMettRNA $f^{\text {Met }}$ on $70 S$ ribosomes.

\section{Discussion}

Previously we used toeprinting to locate a 30 S initiation complex on gene 32 mRNA (Hartz et al. 1988), to iden-

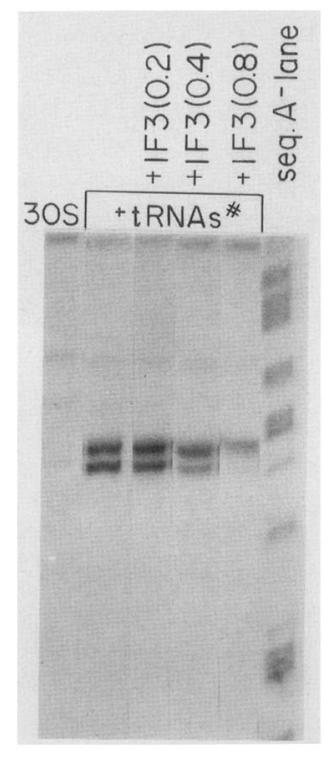

Figure 8. Selection of $\mathrm{A} 22_{\mathrm{f}}^{\text {Met }}$ by IF3. In addition to $0.2 \mu \mathrm{M} 30 \mathrm{~S}$ subunits (left lane), a mixture of A22 Met, tRNACys and tRNA ${ }^{\text {Phe }}$ (tRNAs \#) at $0.5 \mu \mathrm{M}$ each was added. Furthermore, IF3 was added at the concentrations (in $\mu \mathrm{M}$ ) shown in parentheses. A sequencing lane (A lane) is shown at right. 

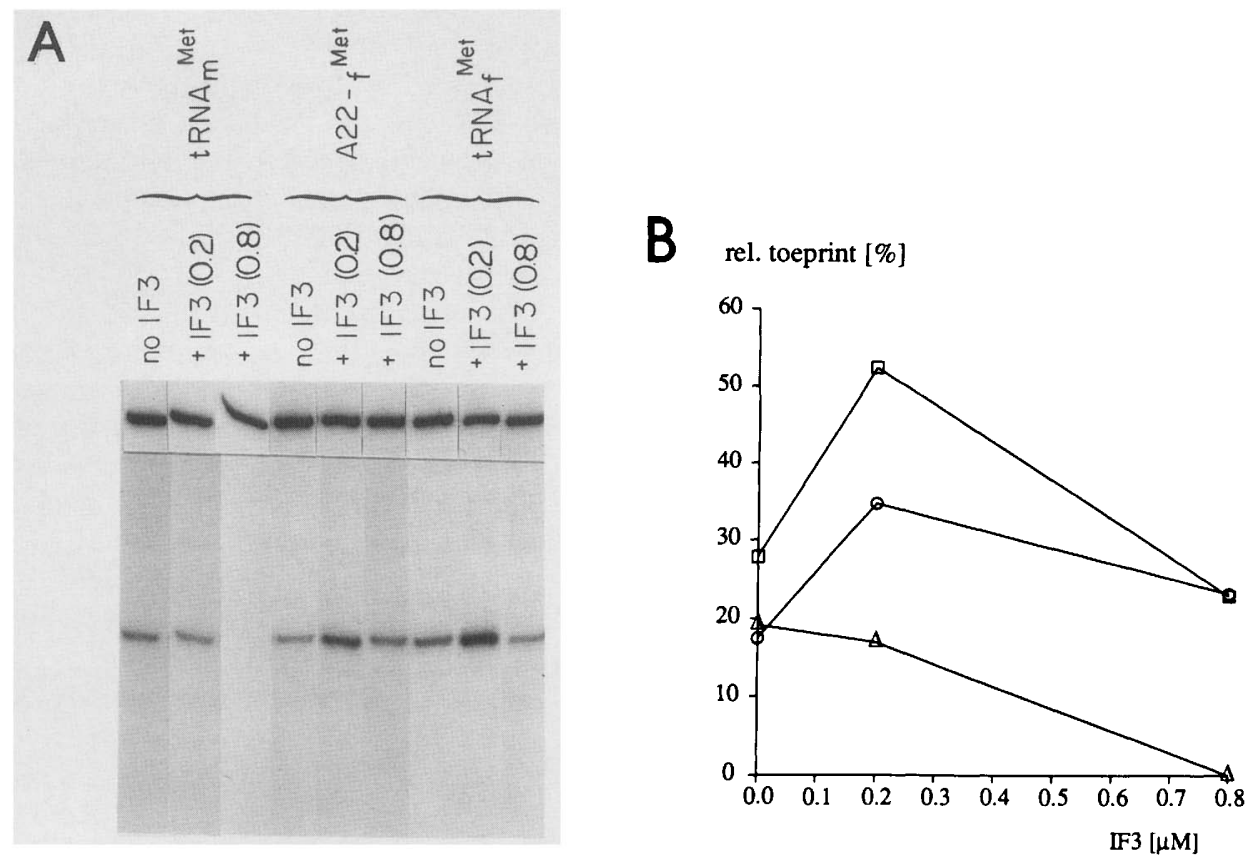

Figure 9. Influence of IF3 on ternary complex formation with single tRNA species. $0.5 \mu \mathrm{M}$ of the elongator tRNA initiator tRNA fragment A22 Met, or $0.5 \mu \mathrm{M}$ of the initiator tRNA concentrations (in $\mu \mathrm{M}$ ) indicated in parentheses above the lanes. Preincubations were for $10 \mathrm{~min}$ at $37^{\circ} \mathrm{C}$. $(A)$ Actual toeprints; the $5^{\prime}$ ends are shown at top. $(B)$ Graph of the relative toeprints, measured by densitometrical scanning; $(\square) \mathrm{tRNA}_{\mathrm{f}}^{\mathrm{Met}} ;(O) \mathrm{A}_{2} 2_{\mathrm{fet}} ;(\triangle)$ tRNA $\mathrm{m}_{\mathrm{m}}^{\text {Met }}$.

tify ribosome-binding sites on the transcript of the E.coli unc operon (Schaefer et al. 1989) and to study discrimination between dual translation initiation sites in the $\lambda$ $S$ gene (Bläsi et al. 1989). Toeprint inhibition analysis has been used to monitor the autogenous translational repression of $\mathrm{T} 4$ gene 32 by gene 32 protein $($ McPheeters et al. 1988) and translational repression of T4 rIIB by regA protein (Winter et al. 1987). Here we used toeprinting to reinvestigate the tRNA-binding properties of translational initiation complexes. Our data complement a large number of experiments that show the $30 \mathrm{~S}$ ribosomal subunit to be capable, itself, of locating the initiation domains of mRNAs. Yet the $30 \mathrm{~S}$ complexes readily accept elongator tRNAs in response to cognate codons within the ribosome-binding site. Thus, a selection mechanism for the initiator tRNA must exist. We have shown that IF2 and IF3 provide initiator tRNA selection in vitro on $30 \mathrm{~S}$ complexes but not on $70 \mathrm{~S}$ initiation complexes. For proper tRNA selection with $70 \mathrm{~S}$ ribosomes, the initiation factor IF 1 is needed along with IF2 and IF3.

\section{S Initiation complexes}

$30 \mathrm{~S}$ particles must be competent to bind to the initiation regions on the mRNA because factor-free $30 \mathrm{~S}$ particles plus initiator tRNA form detectable (by toeprinting) initiation complexes at true initiation codons and not at other AUGs. This is in agreement with the classic experiments of Van Duin and collaborators (Van Duin et al. 1980), which refuted the idea that initiation factor IF3 is necessary for 30S mRNA binding (Suttle and Ravel 1974; see also Maitra et al. 1982; Hershey 1987). The binding of the $30 \mathrm{~S}$ particle to the mRNA serves to diminish the space to be searched in the hunt for the initiation codon. The Shine and Dalgarno sequence, which interacts with the $3^{\prime}$ end of 16S RNA, provides one binding signal and, thus, 'tethers' the $30 \mathrm{~S}$ particle to the mRNA. The $30 \mathrm{~S}$ particle probably searches for the initiation codon within some constrained distance from that tether. The fact that toeprints were mostly observed for codons at a certain distance (3-17 nucleotides) from the Shine and Dalgarno sequence (Table 1) supports such a concept. During the hunt, any tRNA can bind to factorfree $30 \mathrm{~S}$ particles; toeprints (and stable ternary complexes) are formed as long as a cognate codon is within the 'scanning' distance. Many different elongator tRNAs bind to the same tRNA-binding site on factor-free $30 \mathrm{~S}$ subunits, as evidenced by a corresponding shift $1+15$ from the cognate codons) in the $3^{\prime}$ edge of 30 S subunit on the mRNA. The affinity of the elongator tRNAs in initiation complexes varies, as indicated by different toeprint strengths, probably because of the location of cognate codons with respect to the Shine and Dalgarno sequence or other mRNA determinants, or because of an intrinsically higher affinity of some tRNAs for the $30 \mathrm{~S}$ subunit. With several mRNA templates (T4 gene 32, gene 69 , gene 45 , gene 1 , and $\operatorname{reg} A$ ), the elongator tRNAs compete well with the initiator tRNA for the P site. These data are at odds with the traditional picture that the P site on the $30 \mathrm{~S}$ subunit excludes the elongator tRNAs on a natural mRNA template (Nomura and 


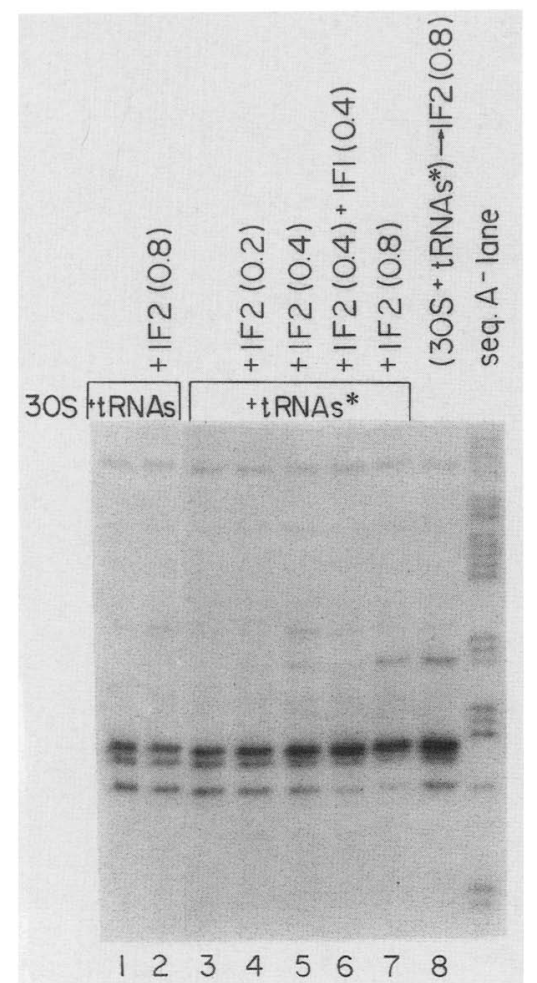

Figure 10. Selection of $\mathrm{fMet}-\mathrm{tRNA} \mathrm{A}_{\mathrm{M}}^{\mathrm{set}}$ by IF2. In addition to $0.2 \mu \mathrm{M}$ 30S subunits (lane 1), lane 2 contained a mixture of the three tRNA species, tRNA ${ }_{\text {Met }}$, tRNACys, tRNA ${ }^{\text {Phe }}$ (tRNAs) at $0.5 \mu \mathrm{M}$ each, and lanes 3-8 contained a mixture of fMettRNA $^{\text {Met }}$, tRNA ${ }^{\text {Cys }}$, tRNA ${ }^{\text {Phe }}$ (tRNAs ${ }^{*}$ ) at $0.5 \mu \mathrm{M}$ each. Furthermore, IF2 or IF1 plus IF2 was added at the concentrations (in $\mu \mathrm{M}$ ) indicated in brackets. Preincubations of lanes 1-7 were for $10 \mathrm{~min}$ at $37^{\circ} \mathrm{C}$. In lane 8 , the reaction containing $30 \mathrm{~S}$ and the mixture of tRNAs ${ }^{\star}$ was preincubated for 10 min before IF2 was added and the preincubation continued for another $10 \mathrm{~min}$. (Right) Sequencing lane (A lane).

Lowry 1967). The previous experiments were done on phage 12 RNA with one labeled tRNA species in an unlabeled tRNA mixture. It is possible that the initiator tRNA competes well with elongator tRNAs on ribosomes programmed with phage $\mathrm{f} 2 \mathrm{RNA}$ as we found for T4 rIIB, orf1, orfD mRNA, and the pRS270 transcript. It should also be noted that contamination of the $30 \mathrm{~S}$ subunit preparation with initiation factors leads to preferred initiator tRNA binding in $30 \mathrm{~S}$ initiation complexes (see below). We encountered such initiator tRNA selection with one $30 \mathrm{~S}$ subunit preparation and found that it actually contained initiation factors. Because elongator tRNAs bind well to $30 \mathrm{~S}$ subunits in reponse to polynucleotides that contain cognate codons (Nomura and Lowry 1967; Risuleo et al. 1976; Canonaco et al. 1986), we conclude that the tRNA-binding characteristics of 30 S subunits are similar with natural mRNAs and polynucleotides as templates. $30 \mathrm{~S}$ subunits bind to specific sites on natural mRNA and thus restrict the codons that can be scanned by a tRNA present in the P site.

Another task for the translational machinery might be the discrimination between uncharged and formylmeth- ionine-charged initiator tRNA. Our titration experiment reveals that tRNA $A_{\mathrm{f}}^{\text {Met }}$ with a $K_{\mathrm{a}}$ of $7.4 \times 10^{7} / \mathrm{M}$ binds almost as well as fMet-tRNA Met with a $K_{\mathrm{a}}$ of $1.0 \times 10^{8} / \mathrm{M}$. The $30 \mathrm{~S}$ subunit probably does not discriminate between the two species, in agreement with a previous report (Rudland and Dube 1969). Furthermore, fMettRNA $A_{f}^{\text {Met }}$ and tRNA $A_{f}^{\text {Met }}$ behave identically in competition experiments with elongator tRNAs. The binding constants found by toeprinting are in the same binding range as the one reported for E.coli Phe-tRNA ${ }^{\text {Phe }}$ binding to poly $(\mathrm{U})$-primed $30 \mathrm{~S}$ complexes with a $K_{\mathrm{a}}$ of $2.5 \times 10^{8} / \mathrm{M}$ at $10 \mathrm{mM} \mathrm{Mg} \mathrm{Mg}^{2+}$ (Kirillov et al. 1980). Yeast tRNA ${ }^{\text {Phe }}$ binding in such complexes gives a lower $K_{\mathrm{a}}$ of $1 \times 10^{7} / \mathrm{M}$ at $30 \mathrm{~mm} \mathrm{Mg}{ }^{2+}$ (Rose et al. 1983). The lower $K_{\mathrm{a}}$ of $1.8 \times 10^{6} / \mathrm{M}$ for the unmodified tRNA anticodon stem and loop fragment A22 ${ }_{f}^{\text {Met }}$ (Fig. 5) is surprising because equally strong binding has been reported for $E$. coli

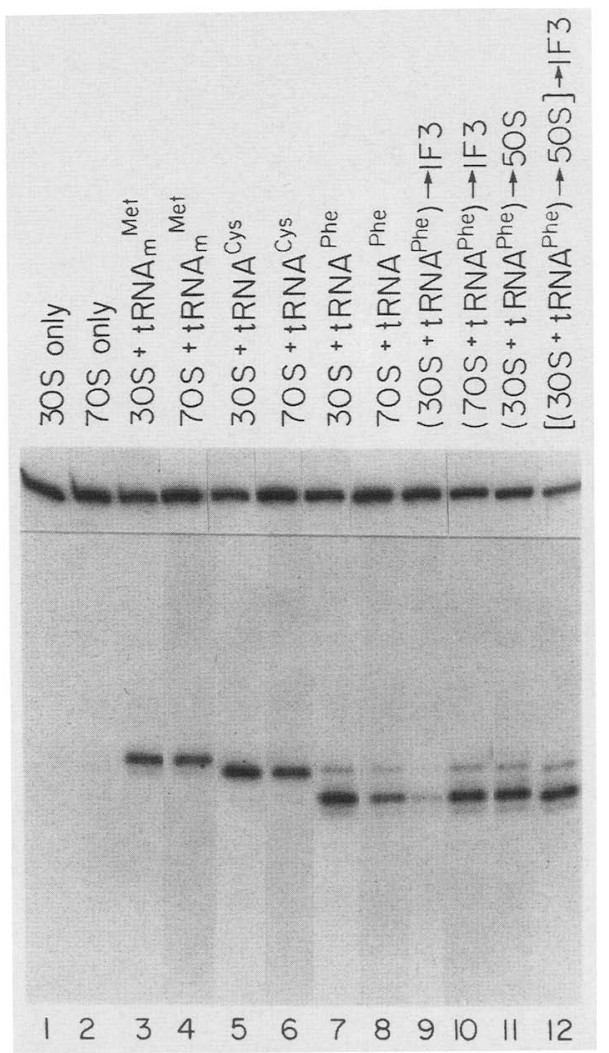

Figure 11. Comparison of $30 \mathrm{~S}$ and $70 \mathrm{~S}$ ternary complexes with elongator tRNAs and IF3. In addition to $0.2 \mu \mathrm{M} 30 \mathrm{~S}$ or 0.2 $\mu \mathrm{M} 70 \mathrm{~S}$ (prepared by preincubating $0.2 \mu \mathrm{M} 30 \mathrm{~S}$ and $0.24 \mu \mathrm{M} 50 \mathrm{~S}$ for $15 \mathrm{~min}$ at $37^{\circ} \mathrm{C}$ ) in lanes 1 and 2 , the tRNA species indicated above the lanes were added at a concentration of $0.5 \mu \mathrm{M}$ (lanes $3-12$ ). In lanes 9-12, the reactions were first incubated with the components in parentheses for $10 \mathrm{~min}$ before the next component (IF3 or 50S) was added. Preincubation was continued for 10 minutes more before reverse transcriptase or the next component (IF3 in lane 12) was added. Lane 12 had a total preincubation time of $30 \mathrm{~min}$, whereas the other lanes had a total preincubation time of $20 \mathrm{~min}$ at $37^{\circ} \mathrm{C}$. The concentration of IF3 added was $0.8 \mu \mathrm{M}$ final, and that of $50 \mathrm{~S}$ was $0.24 \mu \mathrm{M}$ final. For better comparison, $5^{\prime}$ ends are shown at top of the lanes. 


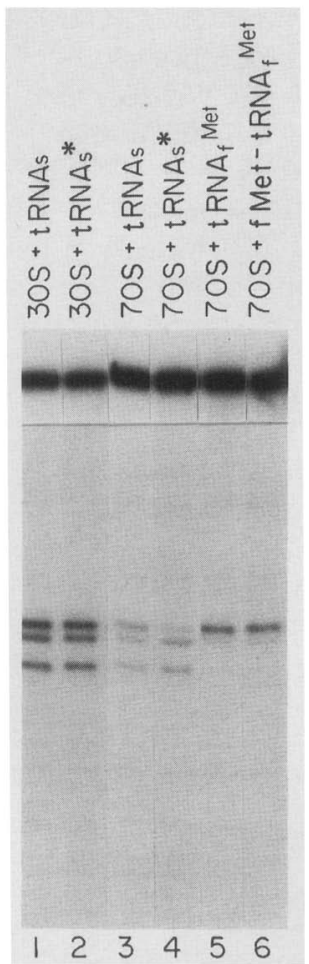

Figure 12. Comparison of initiator tRNA binding in $30 \mathrm{~S}$ and $70 \mathrm{~S}$ ternary complexes. Incubations contained $30 \mathrm{~S}$ or $70 \mathrm{~S}$ (prepared as in Fig. 11) at $0.2 \mu \mathrm{M}$ and a mixture of the tRNA species tRNA Met $^{\text {Met }}$ tRNA ${ }^{\text {Cys }}$, and tRNA ${ }^{\text {Phe }}$ (tRNAs) at $0.5 \mu \mathrm{M}$ each in lanes 1 and 3 or a mixture of the tRNA species fMet-tRNA Met, $^{\text {Met }}$ tRNA $^{\text {Cys }}$, and tRNA ${ }^{\text {Phe }}\left(\right.$ tRNAs $\left.^{*}\right)$ at $0.5 \mu \mathrm{M}$ each in lanes 2 and 4. Lanes 5 and 6 contain $0.2 \mu \mathrm{M} 70 \mathrm{~S}$ ribosomes and $0.5 \mu \mathrm{M}$ tRNA $\mathrm{f}_{\mathrm{f}}^{\text {Met }}$ or $0.5 \mu \mathrm{M}$ fMet-tRNA $\mathrm{f}_{\mathrm{f}}^{\text {Met }}$, respectively. Preincubations were for $10 \mathrm{~min}$ at $37^{\circ} \mathrm{C}$. $5^{\prime}$ ends are shown at top of the lanes.

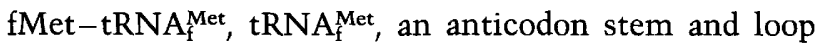

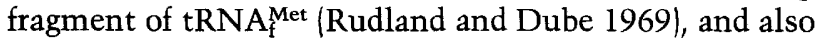
for yeast tRNA ${ }^{\text {Phe }}$ and the anticodon stem and loop fragment thereof (Rose et al. 1983). The weaker toeprints with A22 $2_{\mathrm{f}}^{\text {Met }}$ could either be the result of a lower binding affinity of A22 Met to 30 S subunits or less stable ternary complexes. Both possibilities could well be caused by its unmodified cytidine in the anticodon loop, extraneous nucleotides on the $5^{\prime}$ and $3^{\prime}$ end, or the triphosphate on the $5^{\prime}$ end and do not necessarily mean that some important component for the interaction with the $30 \mathrm{~S}$ particle is missing.

\section{S Initiation complexes with initiation factors}

If the $30 \mathrm{~S}$ subunit cannot discriminate fMet-tRNA $\mathrm{f}_{\mathrm{f}}^{\text {Met }}$ from elongator tRNAs or uncharged tRNA $A_{f}^{\text {Met }}$, what provides the discrimination in the cell? The access of elongator tRNAs to the 30S P site is a serious threat for the proper initiation process and would result either in a shorter protein product or translation of a wrong reading frame.

We show for the first time that IF3 selects the initiator
tRNA on a natural mRNA template. In agreement with Risuleo et al. (1976), we find that IF3 action distinguishes the initiator tRNA from the elongator tRNAs solely because of a unique RNA and not because of its formylmethionine. Furthermore, at least part of the information for initiator tRNA discrimination is located in the fragment A22 Met, which behaves strikingly similar to the whole initiator tRNA with respect to IF3. It has been reported that three GC base pairs adjacent to the anticodon loop are highly conserved in initiator tRNAs (Sprinzl et al. 1987) and that initiator tRNAs have a special anticodon loop conformation (Wrede et al. 1979). The three GC base pairs adjacent to the anticodon loop in the $E$. coli initiator tRNA are important for translational initiation and, when changed, also lead to a different loop conformation (Seong and RajBhandary 1987). These GC base pairs are conserved in the $A 22_{\mathrm{f}}^{\text {Met }}$ fragment and might explain its initiator tRNA-like behavior.

As shown previously, IF3 enhances the exchange rate of elongator tRNAs that are bound in polynucleotideprimed 30S complexes (Pon and Gualerzi 1974). The cor-

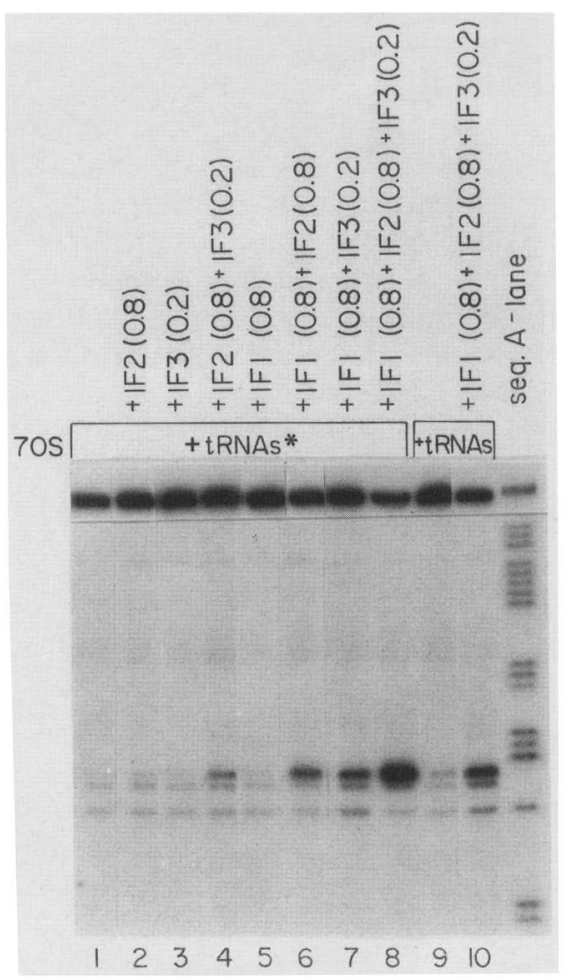

Figure 13. Selection of initiator tRNA on $70 \mathrm{~S}$ complexes. In addition to $0.2 \mu \mathrm{M}$ 70S ribosomes (prepared as in Fig. 11), a mixture of the three tRNA species fMet-tRNAMet tRNA ${ }^{\text {Cys }}$, and tRNA $^{\text {Phe }}\left(\mathrm{tRNAs}^{\star}\right)$ at $0.5 \mu \mathrm{M}$ each was added in lanes $1-8$ or a mixture of the three tRNA species tRNA tRNA $^{\text {Phe }}$ (tRNAs) at $0.5 \mu \mathrm{M}$ each was added in lanes 9 and 10. Initiation factors were added at the concentrations (in $\mu \mathrm{M}$ ) indicated in parentheses above the lanes. Preincubations were for $20 \mathrm{~min}$ at $37^{\circ} \mathrm{C}$. (Right) Sequencing lane (A lane). $5^{\prime}$ ends are shown at the top of the lanes. 
responding initiator tRNA-containing complexes are more resistant to IF3-induced destabilization than are complexes with elongator tRNAs (Risuleo et al. 1976). The results from our tRNA competition experiments on a natural mRNA template are consistent with these earlier data. In agreement with earlier reports (Risuleo et al. 1976; Van der Hofstad et al. 19781, we also found that IF3 acts in a concentration-dependent manner on initiator tRNA-containing complexes. IF3 enhances complex formation at an IF3/30S ratio of $1: 1$, but this effect is reversed at higher IF3/30S ratios. A second binding site for IF3 could exist which, when occupied, inhibits complex formation. More complicated kinetic models are also possible, which require only one IF3-binding site on the $30 \mathrm{~S}$ particle. Unfortunately, concentration-dependent IF3 action led to confusion about the role of IF3. Van der Hofstad et al. (1978) reported that the binding of IF3 and the binding of the initiator tRNA and IF2 were exclusive on the $30 \mathrm{~S}$ subunit and thus proposed a different pathway for initiation complex formation. Their measurements were done at a high IF3/30S ratio. Using an IF3/30S ratio of $1: 1$, Pon and Gualerzi (1986) later showed that the proposed pathway was incorrect for physiologically appropriate initiation factor quantities.

The role of IF3 in initiator tRNA selection has so far been underestimated because of the reports that initiator tRNA binds most strongly to the 30S P site (Bretscher and Marcker 1966; Nomura and Lowry 1967), that IF2 is involved in the binding of the initiator tRNA (Jay and Kaempfer 1974; see below), and that elongator tRNAs are complexed with elongation factor Tu (EFTu) [thus preventing them from binding during initiation (but see Gnirke and Nierhaus 1986)]. Additionally, IF3 was associated with binding of the $30 \mathrm{~S}$ subunit to natural mRNA but not to synthetic polynucleotides (Suttle and Ravel 1974). However, these data for mRNA binding to ribosomes were gained mainly by measuring the initiator tRNA (!) binding in 30 S initiation complexes (Wahba et. al. 1969; Jay and Kaempfer 1974; Suttle and Ravel 1974). The finding that IF3 did not stimulate the binding of fMet-tRNA $A_{f}^{\text {Met }}$ or elongator tRNAs to polynucleotide primed $30 \mathrm{~S}$ but did stimulate the binding of fMettRNA $\mathrm{f}_{\mathrm{f}}^{\text {Met }}$ to natural mRNAs led to an artificial distinction between polynucleotide templates and natural mRNA templates. Our explanations of these data are twofold: (1) IF3 does not stimulate the binding of elongator tRNAs but does stimulate the binding of initiator tRNA as shown in this study; and (2) IF3 probably disso-

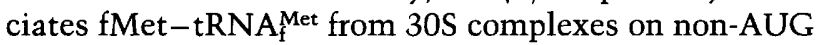
initiation codons of a random poly $(A, U, G)$ template and therefore might not have an overall stimulating effect (Berkhout et al. 1986). Recent measurements of $30 \mathrm{~S}$ mRNA binary complex formation did not indicate any effect of IF3 [nor any effect of the other initiation factors [Calogero et al. 1988)].

IF2 also selects the initiator tRNA in direct competition with elongator tRNAs. This selection is absolutely dependent on the formylmethionine charging of the initiator tRNA. Even though the stimulation of fMettRNA $A_{f}^{\text {Met }}$ binding into $30 S$ initiation complexes by IF 2 is well-documented (Wahba et al. 1969; Dubnoff et al. 1972), a selective function had not been proved. IF2 is able to form binary complexes with initiator tRNA, which is dependent on its formylation (Sundari et al. 1976; Van der Hofstad et al. 1977; Petersen et al. 1983). Nevertheless, IF2 probably acts on the 30S level (Canonaco et al. 1986; Gualerzi and Wintermeyer 1986) and mainly influences the binding of the initiator tRNA to the 30 S subunit (Vermeer et al. 1973), in striking similarity to IF3. Yet the selective mechanism must be different from that of IF3. IF2 does not dissociate the elongator tRNA complexes (as IF3 does) but even stabilizes them (Canonaco et al. 1986). Our data agree with the notion that IF2 selects fMet-tRNA ${ }_{\mathrm{f}}^{\text {Met }}$ by kinetically favoring the steps leading to $30 \mathrm{~S}$ initiation complexes containing fMet-tRNA ${ }_{f}^{\text {Met }}$ (Canonaco et al. 1986). In essence, IF2 action not only discriminates the initiator tRNA from elongator tRNAs but also provides discrimination against uncharged and probably unformylated initiator tRNA. It thus connects the fidelity of translation initiation to the intracellular redox state and the one carbon metabolism via tetrahydrofolate (the formyl group donor); of course, methionine, itself, is the other important component in the one carbon metabolism (Danchin 1973).

\section{S Initiation complexes}

We obtained toeprints with initiator tRNA and elongator tRNAs on factor-free $70 S$ initiation complexes at the same positions (+15 from the codons) as in $30 S$ complexes. The most likely explanation is that these tRNAs bind to the same site as in $30 \mathrm{~S}$ complexes and that the edge of the ribosome into which reverse transcriptase collides is composed of $30 \mathrm{~S}$ material. This finding has implications for the positioning of the $50 \mathrm{~S}$ subunit with respect to the $30 \mathrm{~S}$ subunit and the mRNA. A current model proposes the 50S subunit to be bound to the 30 s subunit away from the mRNA, which is in accordance with our finding (Gold 1988).

Initiation complexes with 705 ribosomes are weaker at toeprinting. The $70 \mathrm{~S}$ complexes are formed more slowly than those with $30 S$ subunits. After $30 S$ complexes have formed, addition of $50 \mathrm{~S}$ subunits yields stronger toeprints from $70 S$ complexes than those obtained when starting the incubation with 705 particles and incubating for the same amount of time. The $70 \mathrm{~S}$ complexes probably do not form via a $30 \mathrm{~S}$ intermediate because fMet-tRNA $_{\mathrm{f}}^{\text {Met }}$ is bound less well than tRNA ${ }^{\mathrm{Cys}}$ and TRNA $^{\text {Phe }}$ in competition experiments on 70 S complexes but is bound equally well on $30 \mathrm{~S}$ complexes (the hypothetical intermediates). These results on a natural mRNA contradict previous data showing that neither initiator nor elongator tRNAs can form $70 S$ complexes directly from $70 S$ on natural mRNA (Nomura and Lowry 1967; Nomura et al. 1967). Most likely, the slower formation of 705 complexes without initiation factors prevented their detection. Our data again indicate a similarity in the behavior of natural mRNA and synthetic polynucleotides, which readily form $70 S$ complexes 
with elongator tRNAs, but not with fMet-tRNAMet if elongator tRNAs are present (Nomura and Lowry 1967; Guthrie and Nomura 1968).

Another way to distinguish $70 S$ from $30 S$ complexes is their behavior with IF3. IF3 does not provide a selection mechanism for the initiator tRNA on $70 \mathrm{~S}$ initiation complexes, as it does on $30 \mathrm{~S}$ initiation complexes. The reason is that IF3 cannot dissociate elongator tRNAs from $70 \mathrm{~S}$ complexes, probably because it does not bind to 70 S (Gottlieb and Davis 1975; Risuleo et al. 1976; Van der Hofstad et al. 1978). The other selector of the initiator tRNA on 30S initiation complexes, IF2, also does not work on $70 \mathrm{~S}$ initiation complexes. How is initiator tRNA selection achieved in vivo? The key component seems to be IF1, which does not select the initiator tRNA. If added together with IF3 or IF2, or both, selection is achieved gradually. We interpret this IFl action as allowing IF3 and IF2 to resume their function on 70S complexes. IF1 could either facilitate IF3 and IF2 action on the $70 S$ subunit or support the dissociation of 705 so that IF3 and IF2 can resume their function on the $30 S$ subunit. We cannot distinguish those two possibilities in our experimental system. We favor the latter possibility; IF1 alters the dissociation of $70 \mathrm{~S}$ by increasing both the forward and backward rates of the association reaction (Godefroy-Colburn et al. 1975). Furthermore, there is good evidence that $30 \mathrm{~S}$ subunits are formed transiently in vivo (Kaempfer et al. 1968; Martin and Webster, 1975), and in vitro experiments indicate that $70 S$ initiation complexes form via a $30 S$ complex intermediate if initiation factors are present (Nomura et al. 1967; Blumberg et al. 1979). All current schemes of translational initiation use a $30 \mathrm{~S}$ complex intermediate (Gualerzi and Pon 1981; Hershey 1987). The dissociation of $70 \mathrm{~S}$ ribosomes in vivo is supported by the low intracellular $\mathrm{Mg}^{2+}$ concentration (Chaires et al. 1981). So far, IF3 has been implicated as the major factor in 70 S dissociation (Kaempfer 1972). If, in the presence of IF1, 70S ribosomes initiate via $30 \mathrm{~S}$ intermediates, IF 1 might be very important for $70 S$ dissociation.

\section{Concluding remarks}

Translational initiation can be thought of in the following way. Termination of translation of any message releases free ribosomal subunits (Martin and Webster 1975). The free $30 \mathrm{~S}$ particle, with or without initiation factors, is able to recognize the initiation domain of most mRNAs so that a new round of translation can occur. In the work reported here, a large number of mRNAs were shown to be recognized in the initiation domain by factor-free $30 \mathrm{~S}$ particles. Recognition of the mRNA effectively tethers the initiation codon and several other codons close to the anticodon of a tRNA bound in the ribosomal $\mathrm{P}$ site. It is these several other codons that present a problem for the initiation process, because at first approximation, factor-free $30 \mathrm{~S}$ subunits do not select one tRNA over another. Recognition of the initiation codon over nearby codons in each message requires the joint action of IF2, IF3, and the initiator
tRNA. The two initiation factors appear to use opposite ends of the tRNA to accomplish selectivity. Finally, IF1 may largely facilitate subunit dissociation, allowing IF2 and IF3 to select the initiator tRNA on the $30 \mathrm{~S}$ particles to which they bind.

\section{Materials and methods}

tRNA

Total $E$. coli tRNA and the uncharged $E$. coli tRNA species tRNA $_{\text {Met }}^{\text {and }}$ tRNA ${ }^{\text {Phe }}$ were purchased from Boehringer-Mannheim. All other tRNAs were purchased from Subriden RNA. fMet-tRNA ${ }^{\text {Met }}$ was prepared by D. Dix and J. Binkly, according to Dubnoff and Maitra (1971). The tRNA preparation used in experiments of Figures 2, 4, and 7 was $\sim 60 \%$ charged and $39 \%$ charged and formylated, and the tRNA preparation used in experiments of Figures 10, 12, and 13 was $\sim 40 \%$ charged and $12 \%$ charged and formylated. The synthetic tRNA fragment A22 Met was generated by $\mathrm{T} 7$ transcription from the fragments pts (top strand) and floop (bottom strand), both shown in Table 2, according to Milligan et al. (1987). The 3 ' nucleotide of purified $\left(20 \%\right.$ polyacrylamide gel electrophoresis) A22 $2^{\text {Met }}$ was determined by $3^{\prime}$-end-labeling with ${ }^{32} \mathrm{pCp}$, according to Beckett and Uhlenbeck (1984), followed by RNase digestion and two-dimensional thin layer chromatogaphy (Nishimura 1972).

\section{Enzymes}

AMV-reverse transcriptase and MMLV-reverse transcriptase were obtained from Life Sciences, and Bethesda Research Laboratories, respectively. T7 RNA polymerase was provided by $\mathrm{O}$. Uhlenbeck. The Klenow fragment of $E$. coli DNA polymerase I, T4 polynucleotide kinase, and T4 RNA ligase were purchased from New England Biolabs.

\section{Initiation factors}

E.coli initiation factors were a kind gift from C. Gualerzi. Initiation factor IF3 was also provided by D. Dix.

\section{Ribosomes}

$30 \mathrm{~S}$ and $50 \mathrm{~S}$ subunits, prepared according to Kenney et al. (1979), were a gift from R. Traut. 70S ribosomes were generated by incubating $30 \mathrm{~S}(0.2 \mu \mathrm{M})+50 \mathrm{~S}(0.24 \mu \mathrm{M})$ in our standard buffer (see below) for $15 \mathrm{~min}$ at $37^{\circ} \mathrm{C}$ prior to use.

\section{mRNAs}

Crude bacteriophage T4 mRNAs were prepared from E. coli NapIV infected with T4-33amN134-55amBL292 and were harvested $12 \mathrm{~min}$ after infection. The procedure for cell growth, infection, and extraction of the RNA is outlined in McPheeters et al. (1986). In vitro RNAs from the PvuII-cut plasmids pRS170 and pRS270 were synthesized with T7 polymerase, according to Lowary et al. (1986). The RNAs were purified on a $6 \%$ polyacrylamide gel.

\section{Plasmids}

The plasmid pRS170 contains the sequence from -92 to 107 of gene 32 (Krisch and Allet 1982), and the plasmid pRS270 contains a synthetic ribosome-binding site as shown in McPheeters et al. (1988). Both sequences are downstream from a T7 promoter. They were constructed by R. Saunders, who cloned the 
Table 2. Description of oligonucleotides

\begin{tabular}{|c|c|c|}
\hline Oligonucleotide & Sequence & mRNA target \\
\hline rIIP3 & cctgttgggtgtaattaccacttg & $r I I B$, from 58 to 81 \\
\hline 32loopD & atcttcagaagaaaaaccttt & gene 32 , from 60 to 80 \\
\hline $32 \mathrm{P} 2$ & get tgaccgttacccgcat & gene 32 , from 109 to 117 \\
\hline nama69 & caccggcagtt tctaat tatctg & gene 69 , from 166 to 189 \\
\hline nama45 & ccgagaaaaccgttcaaatcg & gene 45 , from 164 to 184 \\
\hline pdexl & gaagcttttcgcgaatagtga & orf 1 , from 85 to 106 \\
\hline namat 1 & gtagtatctttccactac & gene 1 , from 31 to 49 \\
\hline rega p1 & ctttat tat tagcaat tcccatac & $\operatorname{reg} A$, from 61 to 84 \\
\hline magnag 47 & cat tgcctctgtttagtcct & orf $D$, from 38 to 57 \\
\hline LP134 & gt tgggtaacgccaggg & lacZ, gene from 57 to 73 \\
\hline pts & taatacgactcactatag & - \\
\hline floop & attatgctgagtgatatccagcccgagtat tgggettc & - \\
\hline
\end{tabular}

gene 32 DNA into the BgIII-cut (and blunted) site of pBC26 (Childs et al. 1985). The small HindIII-SacI fragment was subsequently ligated to the large HindIII-SacI fragment of pT7-2 (U.S. Biochemical Corporation) to yield the pRS170 plasmid. To construct the pRS270 plasmid, the oligodeoxynucleotide corresponding to the synthetic operator region of pTS26 RNA [shown in Fig. 9 of McPheeters et al. (1988)] was ligated to the large HindIII-PstI fragment of pBC26. The small HindIII-SacI fragment of that construct was ligated to the large HindIIISacI fragment of pT7-2.

\section{Oligodeoxynucleotides}

Oligodeoxynucleotides were synthesized on an Applied Biosystems Model 380A DNA Synthesizer and purified by preparative polyacrylamide gel electrophoresis. The sequences and annealing places in the mRNAs are shown in Table 2 .

\section{Extension inhibition}

Extension inhibition (or toeprinting) was performed essentially as described in Hartz et al. (1988) with the following modifications: AMV reverse transcriptase ( $\sim 1$ unit per reaction) was used exclusively for primer extension on crude in vivo RNA and the sequencing reactions. MMLV reverse transcriptase $(\sim 200$ units per reaction) was employed with the in vitro transcripts. In the experiment of Figure 11, only 25 units of MMLV reverse transcriptase was used per reaction. Primers labeled with ${ }^{32} \mathrm{P}$, complementary to the mRNAs of interest (see Table 2), were annealed as described in Hartz et al. (1988). Ten-microliter toeprinting reactions were prepared in standard buffer [10 $\mathrm{mM}$ Tris-acetate (pH 7.4), $60 \mathrm{mM} \mathrm{NH}_{4} \mathrm{Cl}, 6 \mathrm{mM} \beta$-mercaptoethanol, $10 \mathrm{~mm} \mathrm{Mg}$ acetate] and contained either $3 \mu \mathrm{g}$ total RNA or $6.7 \mathrm{nM}$ of the in vitro transcripts, along with ribosomes and tRNAs, as specified in Results. Reactions with all ingredients were prepared on ice and preincubated at $37^{\circ} \mathrm{C}$, as specified in the figure legends, before reverse transcriptase was added while the reactions were incubating.

\section{Binding constants}

The strength of the toeprint stop compared with the extent to which reverse transcriptase reads through to the $5^{\prime}$ end of the mRNA is a measure of how many initiation complexes have formed and 'survived' reverse transcription. The relative toeprint is defined as toeprint stop/ $/ 5^{\prime}$ end plus toeprint stop/, and it reflects the fraction of mRNAs that formed initiation com- plexes. By altering the concentration of tRNA under a saturating concentration of $30 \mathrm{~S}$ subunits and limiting mRNA concentration, the relative toeprint should reflect the binding of the tRNA into the $30 \mathrm{~S}$ initiation complex. To quantify the toeprint stop and the 5 '-end stop, the autoradiographs were scanned on a Hoffer GS300 densitometer, and the peaks electronically integrated. The amount of complexes formed was subtracted from the original tRNA concentration to calculate the free tRNA concentration. A bimolecular binding function using an algorithm of Caceci and Cacheris (1984) was fitted to the binding data. The best fit was obtained when a relative toeprint of $40 \%$ for fMet-tRNA Met $_{\mathrm{f}}, 42 \%$ for tRNA $\mathrm{Aet}_{\mathrm{m}}^{\mathrm{Met}}$, and $53 \%$ for A22 Met was assumed as maximal binding $(100 \%)$.

\section{Acknowledgments}

We thank J. Binkley for the preparation of fMet-tRNAMet and $D$. Dix for the provision of initiation factor IF3 and fMettRNAMet. We also thank R. Traut for the provision of $30 \mathrm{~S}$ and $50 S$ ribosomal subunits and $R$. Saunders for constructing the pRS170 and pRS270 plasmids. We could have done little of this work if C. Gualerzi had not given us a large supply of purified $E$. coli initiation factors. We are also grateful to E. Fish, T. Hollingsworth, D. Irvine, and C. Tuerk for their helpful discussions. This work was supported by a research grant from the National Institutes of Health (GM-28685).

\section{Note added in proof}

The competition of tRNA ${ }^{\text {Cys }}$ and tRNA ${ }^{\text {Phe }}$ with initiator tRNA and the selection of initiator tRNA by IF3 seen in Figure 7 (at 10 $\mathrm{mM} \mathrm{Mg}^{2+}$ ) are also observed at the more physiological $\mathrm{Mg}^{2+}$ concentration of $6 \mathrm{mM} \mathrm{Mg}^{2+}$. This corresponds to an even lower free $\mathrm{Mg}^{2+}$ concentration as the reactions contain $1.5 \mathrm{mM}$ nucleoside triphosphates.

\section{References}

Beckett, D. and O.C. Uhlenbeck. 1984. Enzymatic synthesis of oligoribonucleotides. In Oligonucleotide synthesis, a practical approach (ed. M.J. Gait), pp. 185-197. IRL Press, Oxford.

Berkhout, B., C.J. Van der Laken, and P.H. Van Knippenberg. 1986. Formylmethionyl-tRNA binding to 30 S ribosomes programmed with homopolynucleotides and the effect of translational initiation factor 3. Biochim. Biophys. Acta 866: 144-153. 
Bläsi, U., K. Nam, D. Hartz, L. Gold, and R. Young. 1989. Dual translational initiation sites control function of lambda $S$ gene. EMBO f. 8: 3501-3510.

Blumberg, B.M., T. Nakamoto, and F.J. Kezdy. 1979. Kinetics of initiation of bacterial protein synthesis. Proc. Natl. Acad. Sci. 76: 251-255.

Bretscher, M.S. and K.A. Marcker. 1966. Amino-acyl-ribonucleic acid binding sites on ribosomes. Nature 211: 380-384.

Caceci, M.S. and W.P. Cacheris. 1984. Fitting curves to data. The simplex algorithm is the answer. Byte 9: 340-362.

Calogero, R.A., C.L. Pon, M.A. Canonaco, and C.O. Gualerzi. 1988. Selection of the mRNA translational initiation region by Escherichia coli ribosomes. Proc. Natl. Acad. Sci. 85: 6427-6431.

Canonaco, M.A., R.A. Calogero, and C.O. Gualerzi. 1986. Mechanism of translational initiation in procaryotes. Evidence for a direct effect of IF2 on the activity of the $30 \mathrm{~S}$ ribosomal subunit. FEBS Lett. 207: 198-204.

Chaires, J.B., C. Pande, and A. Wishina. 1981. The effect of initiation factor IF-3 on Escherichia coli ribosomal subunit association kinetics. I. Biol. Chem. 256: 6600-6607.

Childs, J., K. Villanueba, D. Barrick, T.D. Schneider, G. Stormo, L. Gold, M. Leitner, and M. Caruthers. 1985. Ribosome binding site sequences and function. In Sequence specificity in transcription and translation (ed. R. Calendar and L. Gold), pp. 341-350. Alan R. Liss, New York.

Danchin, A. 1973. Does formylation of initiator tRNA act as a regulatory signal in E. coli? FEBS Lett. 34:327-332.

Dubnoff, J.S. and U. Maitra. 1971. Isolation and properties of protein factors involved in polypeptide chain initiation in Escherichia coli. Methods Enzymol. 20: 248-261.

Dubnoff, J.S., A.H. Lockwood, and U. Maitra. 1972. Studies on the role of guanosine triphosphate in polypeptide chain initiation in Escherichia coli. J. Biol. Chem. 247: 2884-2894.

Gnirke, A. and K.H. Nierhaus. 1986. tRNA binding sites on the subunits of Escherichia coli ribosomes. I. Biol. Chem. 261: 14506-14514.

Godefroy-Colburn, T., A.D. Wolfe, J. Dondon, M. GrunbergManago, P. Dessen, and D. Pantaloni. 1975. Light-scattering studies showing the effect of initiation factors on the reversible dissociation of Escherichia coli ribosomes. I. Mol. Biol. 94: 461-478.

Gold, L. 1988. Post-transcriptional regulatory mechanisms in E. coli. Annu. Rev. Biochem. 57: 199-233.

Gold, L. and G. Stormo. 1987. Translational initiation. In Escherichia coli and Salmonella typhimurium /ed. F.C. Neidhardt, J.L. Ingraham, K.B. Low, B. Magasanik, M. Schaechter, and H.E. Umbarger), vol. 2, pp. 1302-1307. American Society for Microbiology, Washington, D.C.

Gold, L., D. Pribnow, T. Schneider, S. Shinedling, B.S. Singer, and G. Stormo. 1981. Translation initiation in procaryotes. Annu. Rev. Microbiol. 35: 365-403.

Gottlieb, M. and B.D. Davis. 1975. The irreversible step in formation of initiation complexes of Escherichia coli. Biochemistry 14: 1047-1051.

Gualerzi, C. and C.L. Pon. 1981. Protein biosynthesis in procaryotic cells: Mechanism of 305 initiation complex formation in Escherichia coli. In Structural aspects of recognition and assembly in biological macromolecules (ed. L. Balaban, J.L. Sussman, W. Traub, and A. Yonath), pp. 805-826. Balaban ISS, Rehovot and Philadelphia.

Gualerzi, C.O. and W. Wintermeyer. 1986. Procaryotic initiation factor 2 stopped-flow study. FEBS Lett. 202: 1-6.

Gualerzi, C.O., C.L. Pon, R.T. Pawlik, M.A. Canonaco, M. Paci, and W. Wintermeyer. 1986. Role of initiation factors in Escherichia coli translational initiation. In Structure, func- tion, and genetics of ribosomes (ed. B. Hardesti and G. Kramer), pp. 621-641. Springer-Verlag, New York.

Guthrie, C. and M. Nomura. 1968. Initiation of protein synthesis: A critical test of the $30 \mathrm{~S}$ subunit model. Nature 219: 232-235.

Hartz, D., D.S. McPheeters, R. Traut, and L. Gold. 1988. Extension Inhibition analysis of translation initiation complexes. Methods Enzymol. 164: 419-425.

Hershey, J.W.B. 1987. Protein synthesis. In Escherichia coli and Salmonella typhimurium (ed. F.C. Neidhardt, J.L. Ingraham, K.B. Low, B. Magasanik, M. Schaechter, and H.E. Umbarger), vol. 1, pp. 613-647. American Society for Microbiology, Washington, D.C.

Jay, G. and R. Kaempfer. 1974. Sequence of events in initiation of translation: A role for initiator transfer RNA in the recognition of messenger RNA. Proc. Natl. Acad. Sci. 71: 31993203.

Kaempfer, R. 1972. Initiation factor IF-3: A specific inhibitor of ribosomal subunit association. J. Mol. Biol. 71: 583-598.

Kaempfer, R.O.R., M. Meselson, and H.J. Raskas. 1968. Cyclic dissociation into stable subunits and re-formation of ribosomes during bacterial growth. J. Mol. Biol. 31: 277-289.

Kenney, J.W., T.G. Fanning, J.M. Lambert, and R.R. Traut. 1979. The subunit interphase of the Escherichia coli ribosome. Crosslinking of $30 \mathrm{~S}$ protein S9 to proteins of the $50 \mathrm{~S}$ subunit. J. Mol. Biol. 135: 151-170.

Kirillov, S.V., V.I. Makhno, and Y.P. Semenkov. 1980. Mechanism of codon-anticodon interaction in ribosomes. Direct functional evidence that isolated $30 \mathrm{~S}$ subunits contain two codon-specific binding sites for transfer RNA. Nucleic Acids Res. 8: 183-196.

Kozak, M. 1983. Comparison of initiation of protein synthesis in procaryotes, eucaryotes and organelles. Microbiol. Rev. 47: 1-45.

Krisch, H. and B. Allet. 1982. Nucleotide sequences involved in bacteriophage T4 gene 32 translational self-regulation. Proc. Natl. Acad. Sci. 79: 4937-4941.

Lowary, P., J. Sampson, J. Milligan, D. Groebe, and O.C. Uhlenbeck. 1986. A better way to make RNA for physical studies. In Structure and dynamics of RNA (ed. P.H. van Knippenberg and C.W. Hilbers), pp. 69-76. Plenum Press, New York.

Maitra, U., E.A. Stringer, and A. Chanduri. 1982. Initiation factors in protein biosynthesis. Annu. Rev. Biochem. 51: 869-900.

Martin, J. and R.E. Webster. 1975. The in vitro translation of a terminating signal by a single Escherichia coli ribosome The fate of the subunits. I. Biol. Chem. 250: 8132-8139.

McPheeters, D.S., G.D. Stormo, and L. Gold. 1988. The autogenous regulatory site on the bacteriophage T4 gene 32 messenger RNA. J. Mol. Biol. 201: 517-535.

McPheeters, D.S., A. Christensen, E.T. Young, G. Stormo, and L. Gold. 1986. Translational regulation of expression of the bacteriophage T4 lysozyme gene. Nucleic Acids Res. 14: 5813-5826.

Milligan, J.F., D.R. Groebe, G.W. Witherell, and O.C. Uhlenbeck. 1987. Oligoribonucleotide synthesis using T7 RNA polymerase and synthetic DNA templates. Nucleic Acids Res. 15: 8783-8798.

Nishimura, S. 1972. Minor components in transfer RNA: Their characterization, location, and function. Prog. Nucleic Acids Res. Mol. Biol. 12: 49-85.

Nomura, M. and C.V. Lowry. 1967. Phage F2 RNA-directed binding of formylmethionyl-TRNA to ribosomes and the role of $30 \mathrm{~S}$ ribosomal subunits in initiation of protein synthesis. Proc. Natl. Acad. Sci. 58: 946-953. 
Nomura, M., C.V. Lowry, and C. Guthrie. 1967. The initiation of protein synthesis: Joining of the $50 \mathrm{~S}$ ribosomal subunit to the initiation complex. Proc. Natl. Acad. Sci. 58: 14871493.

Petersen, H.U., F.P. Wikman, G.E. Siboska, H. Worm-Leonhard, and B.F.C. Clark. 1983. Interaction between methionine-accepting tRNAs and proteins during initiation of procaryotic translation. In Gene expression (ed. B.F.C. Clark and H.U. Petersen), pp. 41-57. Alfred Benzon Symposium 19. Munksgard, Copenhagen.

Pon, C.L. and C. Gualerzi. 1974. Effect of initiation factor 3 binding on the $30 \mathrm{~S}$ ribosomal subunits of Escherichia coli. Proc. Natl. Acad. Sci. 71: 4950-4954.

- 1986. Mechanism of translational initiation in procaryotes. IF3 is released from ribosomes during and not before $70 S$ initiation complex formation. FEBS Lett. 195: 215-219.

Risuleo, G., C. Gualerzi, and C. Pon. 1976. Specificity and properties of the destabilization, induced by initiation factor IF-3, of ternary complexes of the 30-S ribosomal subunit, aminoacyl-tRNA and polynucleotides. Eur. I. Biochem. 67: 603-613.

Rose III, S.J., P.T. Lowary, and O.C. Uhlenbeck. 1983. Binding of the yeast tRNA ${ }^{\text {Phe }}$ anticodon arm to Escherichia coli $30 \mathrm{~S}$ ribosomes. I. Mol. Biol. 167: 103-117.

Rudland, P.S. and S.K. Dube. 1969. Specific interaction of initiator tRNA fragment with $30 \mathrm{~S}$ ribosomal subunits. $/$. Mol. Biol. 43: 273-280.

Schaefer, E.M., D. Hartz, L. Gold, and R.D. Simoni. 1989. Ribosome binding sites and RNA processing sites in the transcript of the unc operon of Escherichia coli. I. Bacteriol. 171: $3901-3908$.

Seong, B.L. and U.L. RajBhandary. 1987. Escherichia coli formylmethionine tRNA: Mutations in ${ }_{C}{ }_{C}{ }_{C}{ }_{C}$ sequence conserved in anticodon stem of initiator tRNAs affect initiation of protein synthesis and conformation of anticodon loop. Proc. Natl. Acad. Sci. 84: 334-338.

Sprinzl, M., T. Hartmann, F. Meissner, J. Moll, and T. Vorderwülbecke. 1987. Compilation of tRNA sequences and sequences of tRNA genes. Nucleic Acids Res. (suppl.) 15: r53rl88.

Stormo, G. 1986. Translation initiation. In Maximizing gene expression (ed. W. Reznikoff and L. Gold), pp. 195-224. Butterworth, Boston.

Subramanian, A.R. and B.D. Davis. 1970. Activity of initiation factor F3 in dissociating Escherichia coli ribosomes. Nature 228: $1273-1275$.

Sundari, R.M., E.A. Stringer, L.H. Schulman, and U. Maitra. 1976. Interaction of bacterial initiation factor 2 with initiator tRNA. J. Biol. Chem. 251: 3338-3345.

Suttle, D.P. and J. Ravel. 1974. The effects of initiation factor 3 on the formation of $30 \mathrm{~S}$ initiation complexes with synthetic and natural messengers. Biochem. Biophys. Res. Commun. 57: 386-393.

Van der Hofstad, G.A.J.M., A. Buitenhek, L. Bosch, and H.O. Voorma. 1978. Initiation factor IF-3 and the binary complex between initiation factor IF-2 and formylmethionyl-tRNA are mutually exclusive on the $30-\mathrm{S}$ ribosomal subunit. Eur. J. Biochem. 89: 213-220.

Van der Hofstad, G.A.J.M., J.A. Foekens, L. Bosch, and H.O. Voorma. 1977. The involvement of a complex between formylmethionyl-tRNA and initiation factor IF-2 in procaryotic initiation. Eur. J. Biochem. 77: 69-75.

Van Duin, J., G.P. Overbeek, and C. Backendorf. 1980. Functional recognition of phage RNA by $30-S$ ribosomal subunits in the absence of initiator tRNA. Eur. J. Biochem. 110: 593597.
Vermeer, C., W. Van Alphen, P. Van Knippenberg, and L. Bosch. 1973. Initiation factor-dependent binding of MS2 RNA to $30-S$ ribosomes and the recycling of IF3. Eur. I. Biochem. 40: $295-308$

Wahba, A.J., K. Iwasaki, M.J. Miller, S. Sabol, M.A.G. Sillero, and C. Vasquez. 1969. Initiation of protein synthesis in Escherichia coli. II. Role of the initiation factors in polypeptide synthesis. Cold Spring Harbor Symp. Quant. Biol. 34: 291-299.

Winter, R.B., L. Morrissey, P. Gauss, L. Gold, T. Hsu, and J. Karam. 1987. Bacteriophage T4 regA protein binds to mRNAs and prevents translation initiation. Proc. Natl. Acad. Sci. 84: 7822-7826.

Wintermeyer, W. and C. Gualerzi. 1983. Effect of Escherichia coli initiation factors on the kinetics of N-AcPhe-tRNA ${ }^{\text {phe }}$ binding to $30 \mathrm{~S}$ ribosomal subunits. A fluorescence stoppedflow study. Biochemistry 22: 690-694.

Wrede, P., N. Woo, and A. Rich. 1979. Initiator tRNAs have a unique anticodon loop conformation. Proc. Natl. Acad. Sci. 76: 3289-3293. 


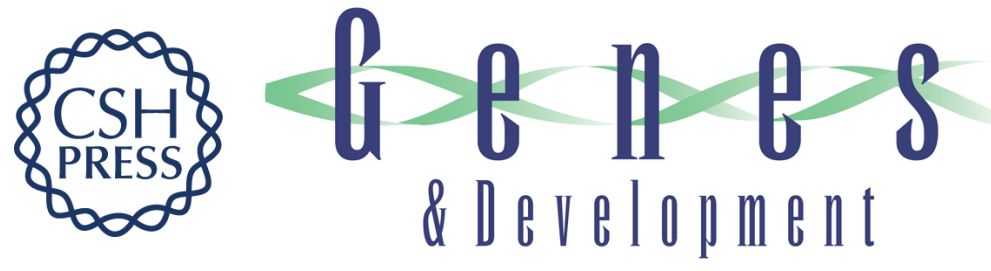

\section{Selection of the initiator tRNA by Escherichia coli initiation factors.}

D Hartz, D S McPheeters and L Gold

Genes Dev. 1989, 3:

Access the most recent version at doi:10.1101/gad.3.12a.1899

References This article cites 53 articles, 18 of which can be accessed free at: http://genesdev.cshlp.org/content/3/12a/1899.full.html\#ref-list-1

License

Email Alerting

Receive free email alerts when new articles cite this article - sign up in the box at the top Service right corner of the article or click here.

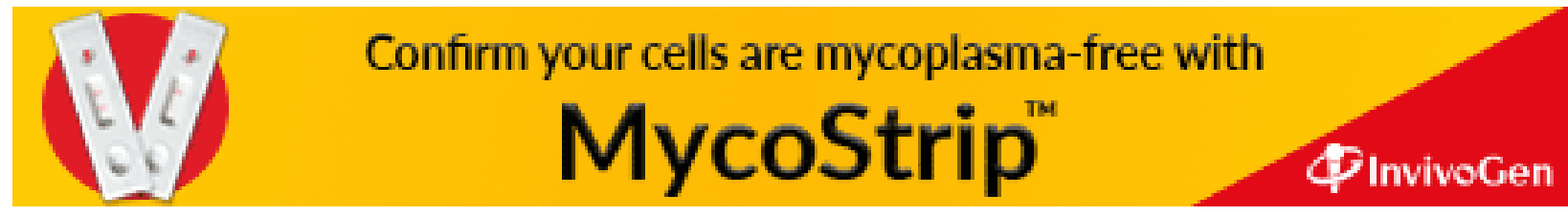

